\title{
How the chemical composition and heterogeneity of crop residue mixtures decomposing at the
} soil surface affects $\mathbf{C}$ and $\mathbf{N}$ mineralization

Marciel Redin ${ }^{1}$, Sylvie Recous ${ }^{2,3}$, Celso Aita ${ }^{1}$, Guilherme Dietrich ${ }^{1}$, Alex Caitan Skolaude ${ }^{1}$, Willian Hytalo Ludke ${ }^{1}$, Raquel Schmatz ${ }^{1}$, Sandro José Giacomini ${ }^{1}$

${ }^{1}$ Federal University of Santa Maria, Department of Soil Science, 97119-900 Santa Maria, RS, Brazil

${ }^{2}$ INRA, UMR614 Fractionnement des AgroRessources et Environnement, F-51000 Reims, France

${ }^{3}$ Université Reims-Champagne Ardenne, UMR614 Fractionnement des AgroRessources et Environnement, 51100 Reims, France

\begin{abstract}
The effects of plant litter characteristics on its decomposition in soil or at the soil surface is of primary importance for adequate management of nutrients and carbon (C) in agro-ecosystems. However, understanding the influence of mixtures of residues, which is actually the most common situation encountered in agriculture, is still poorly known in cultivated soils. Therefore we analyzed the effect of mixing leaf and stem litters from 25 species of plants (main crops and cover crops), representative of agricultural systems in subtropical conditions, on subsequent $\mathrm{C}$ and nitrogen $(\mathrm{N})$ mineralization. We characterized the chemistry of leaves, stems and mixtures and determined the heterogeneity of the mixtures using Gower's similarity coefficient. We incubated crop residues at the surface of a sandy loam soil at $25^{\circ} \mathrm{C}$ over 120 days and continuously measured the mineralization of $\mathrm{C}$ and $\mathrm{N}$. The 25 mixtures represented a wide range of chemical qualities and heterogeneity. Significant differences in $\mathrm{C}$ mineralization and soil $\mathrm{N}$ accumulation clearly differentiated crop families (notably Poaceae species vs. Fabaceae species), and plant parts (stems vs. leaves). The differences between observed and expected values for $\mathrm{C}$ mineralization were low or nil, indicating mostly an additive effect of mixing. Significant synergetic effects existed for only 7 species and resulted in an average additional 9\% C mineralized. For N, an antagonistic effect was observed only with Fabaceae mixtures having
\end{abstract}

high average $\mathrm{N}$ content and high chemical heterogeneity. We concluded that the decomposition of mixtures appeared mainly controlled by their average chemical composition and to a less degree by their chemical heterogeneity. In these cases, the availability of $\mathrm{N}$ in the mixtures appeared to increase the microbial $\mathrm{N}$ immobilization, reducing the net accumulation of mineral $\mathrm{N}$ in the soil.

Keywords: decomposition; chemical composition; functional trait; leaf; stem; litter mixture

\section{Introduction}

No-till systems use a large diversity of crop plant species that directly influence the cycles of carbon (C) and nitrogen (N) in soil (Jensen et al., 2005). In these cropping systems, the crop residues form mulch at the soil surface composed of a mixture of different plant parts (Lal et al., 2007; Thippayarugs et al., 2008). Physical factors (of soil or residue) and biological processes either individually or in combination can drive decomposition, but the intrinsic characteristics, or functional traits, of crop residues are important in controlling their decomposition rate in soils (Trinsoutrot et al., 2000; Jensen et al., 2005; Aulen et al., 2012). In general, leaves have higher rates of $\mathrm{C}$ and $\mathrm{N}$ mineralization than stems (Cobo et al., 2002; Abiven et al., 2005; Thippayarugs et al., 2008) 
due to their more readily decomposable tissue composition, lower lignin content and higher total N content (Quemada and Cabrera, 1995; Bertrand et al., 2006).

Many studies have been performed to better understand the effect of plant residue quality on $\mathrm{C}$ or $\mathrm{N}$ mineralization using plant leaves, stems or mixtures (shoots), with residues incorporated into the soil (e.g., Abiven et al., 2005; Bertrand et al., 2006; Thippayarugs et al., 2008) or left on the soil surface (Quemada and Cabrera, 1995; Cobo et al., 2002, Li et al., 2013a,b). However, in field conditions, different types of plant residues often decompose together in a mixture (Hättenschwiler et al., 2005). Indeed, this question is attracting much attention, particularly in the field of ecology, in investigations of the role of functional diversity (in this case, diversity of plant traits) on ecosystem functioning (Hättenschwiler et al., 2005). Trait similarity measures are used to characterize differences in chemical and physical characteristics of plant litters and to analyze non-additive effects (Gessner et al., 2010; De Bello et al., 2013). The C and N mineralization of litter mixtures can differ from that expected based on the decomposition of single components because the composition of the residue can modify the processes involved in decomposition (Hoorens et al., 2002; Gartner and Cardon, 2004; Berglund et al., 2013). The decomposition of residue mixtures has been reported to exhibit synergistic effects (i.e., higher rates of decomposition than expected) (Quemada and Cabrera, 1995; Zeng et al., 2010), negative effects (i.e., lower rates than expected) or additive effects (i.e., rates equal to those expected) (Liu et al., 2007; Li et al., 2013a; Li et al., 2013b). However, high variations in the range of responses of decomposition rates to mixing have been observed (Gartner and Gardon, 2004) depending on the type of residue, time scale and process considered (e.g., mass loss, C mineralization or $\mathrm{N}$ dynamics). Non-additive effects of mixing residues were assumed to result from the chemical heterogeneity of the mixtures (Harguindeguy et al., 2008) and particularly to the transfer of $\mathrm{N}$ between $\mathrm{N}$-rich and N-poor litters (Berglund et al., 2013). Despite its acknowledged importance, this issue has been rarely addressed in agricultural systems, (Garnier and Navas, 2012). In this context, the published studies about residue mixtures usually involved a small number of species, which makes it difficult to generalize the findings (Gartner and Gardon, 2004). In addition, these studies have analyzed most often $\mathrm{C}$ mineralization or that of $\mathrm{N}$, but rarely both together (e.g., Quemada and Cabrera, 1995; Shi and Marschner, 2014), which is needed to understand the interactions between decomposition and $\mathrm{N}$ dynamics in soil.

Thus, the primary objective of the present study was to quantify, in an agricultural context, the effect of mixing crop residues (leaf and stem) left at the soil surface on their decomposition ( $\mathrm{C}$ mineralization) and the associated soil $\mathrm{N}$ dynamics. We had the aim of exploring a wide variety of quality of mixtures in order to be better able to generalize the results for arable crops. To do so, we used crop residues (leaves, stems and mixtures of leaves and stems) obtained from 25 different crop species grown in field, from five botanical families, mainly Fabaceae and Poaceae, and incubated them under controlled conditions. We tested the proposed hypothesis from Harguindegy et al. (2008) that the effects of mixing crop residues will depend on both the average chemical quality of mixtures, and of the heterogeneity of the components of these mixtures and that these factors would affect $\mathrm{C}$ and $\mathrm{N}$ dynamics differently.

\section{Materials and methods}

\subsection{Collection of plant material}

Twenty-five representative species of plants (main crops or cover crops) of agricultural systems in Brazil were studied (Table 1). The plants selected included eleven Fabaceae (legumes), ten Poaceae (Gramineae), two Brassicaceae, one Euphorbiaceae and one 
Asteraceae. The plants were cultivated during the spring/summer (14 species) and autumn/winter (11 species) in a Typic Hapludalf soil under a no-till system in the experimental area of the Soil Department $\left(29^{\circ} 41^{\prime} \mathrm{S}, 53^{\circ} 48^{\prime} \mathrm{W}\right.$; approximately $90 \mathrm{~m}$ elevation) of the Federal University of Santa Maria in the state of Rio Grande do Sul, Brazil. The region has a subtropical climate with a mean annual precipitation of $1,686 \mathrm{~mm}$ and a mean air temperature of $19.3^{\circ} \mathrm{C}$. For the previous 12 years, the experimental site had been cultivated using a no-till system. All the crops were managed according to the technical recommendations for the area. Plant shoots with 3 field replicates were collected at flowering and harvest for species of cover crops and main crops, respectively. The leaves senescing before harvest were collected gradually until harvest and stored. Subsequently, the plant shoots were separated into leaves and stems to determine their proportion in each plant species (Table 1). First, the residues were dried at $40^{\circ} \mathrm{C}$ and the leaves and stems were cut into pieces $1 \mathrm{~cm}$ long. Then, the residues were cut again along the length into pieces with a thickness of approximately 0.5 to $0.3 \mathrm{~cm}$ for leaves and stems, respectively. Mixtures of leaves and stems were prepared with a leaf:stem ratio for each species similar to the ratio in dry biomass determined in the field (Table 1). One subsample of each residue (leaf, stem and mixture) per species was dried at $40^{\circ} \mathrm{C}$ and ground to $1 \mathrm{~mm}$ particles, and a second subsample of each type of residue was dried at $65^{\circ} \mathrm{C}$ and finely ground $(<1 \mathrm{~mm})$ for chemical analyses.

\subsection{Chemical characterization of plant residues}

The total organic $\mathrm{C}$ and total $\mathrm{N}$ contents of the leaves, stems and mixtures of leaves + stems were determined in a finely ground subsample dried at $65^{\circ} \mathrm{C}$ using an elemental autoanalyzer (FlashEA 1112, Thermo Finnigan, Milan, Italy). A proximate analysis using the Van Soest method was performed using subsamples of ground residues pre-dried at $40^{\circ} \mathrm{C}$. The soluble (SOL), cellulose (CEL), hemicellulose (HEM) and lignin (LIG) fractions of the residues were determined by proximate analysis (Van Soest, 1963). Neutral digestion was performed with $0.3 \mathrm{~g}$ of residues and $30 \mathrm{ml}$ of neutral detergent solution. For acid digestion, $0.6 \mathrm{~g}$ of residues and $60 \mathrm{ml}$ of detergent solution acid were used. The digestions were performed by boiling the material in the digester block at $150^{\circ} \mathrm{C}$ for 1 hour. After digestion, the samples were filtered by vacuum suction using a filter crucible and then washed with hot distilled water $\left(90^{\circ} \mathrm{C}\right)$ and acetone $(30-40 \mathrm{ml})$. The fibers were dried at $105^{\circ} \mathrm{C}$ for $12 \mathrm{~h}$. The SOL content was determined based on the difference in the weight before and after neutral digestion. The HEM content was determined based on the difference between the percentage of total neutral fiber and the percentage of acid detergent fiber. The CEL content of the acid fiber was obtained after digestion with $12 \mathrm{M}$ $\mathrm{H}_{2} \mathrm{SO}_{4}$ for $3 \mathrm{~h}$, and the material remaining after quantification of the CEL content was burned in a muffle furnace at $500^{\circ} \mathrm{C}$ for $3 \mathrm{~h}$ to determine the LIG content.

The water-soluble organic $\mathrm{C}(\mathrm{Csw})$ and water-soluble total $\mathrm{N}$ (Nsw) were extracted using $0.5 \mathrm{~g}$ of finely ground residues pre-dried at $40^{\circ} \mathrm{C}$. The residues were placed in a $60-\mathrm{ml}$ snap cap with distilled water $\left(20^{\circ} \mathrm{C}\right)$ and mechanically stirred for $30 \mathrm{~min}$. After mixing, the material was filtered (Whatman $n^{\circ} 5$ ), and the contents of Csw and Nsw in the filtrate were determined at $65^{\circ} \mathrm{C}$. The quantification of soluble polyphenols (POL) was conducted with $0.75 \mathrm{~g}$ of finely ground residues pre-dried at $40^{\circ} \mathrm{C}$. POL extraction was performed with aqueous methanol $(1: 1)$ in a water bath at $80^{\circ} \mathrm{C}$ for 1 hour (Tian et al., 1995). After extraction, the aqueous solution was filtered (Whatman $\mathrm{n}^{\circ} 2$ ). After addition of the Follin-Denis reagent, the POL content was determined by colorimetry (absorbance at $760 \mathrm{~nm})$ (King and Health, 1967). All the analyses were performed with three replicates, and the summarized results are shown in Table 2. 
Final version of manuscript published in: Soil Biology and Biochemistry, 2014, DOI 10.1016/j.soilbio.2014.07.014

Table 1: Description, agricultural use of crops used and proportion of their leaves and stems determined in field (\% total of DM).

\begin{tabular}{|c|c|c|c|c|c|c|}
\hline Latin name & English name & Family & Plant use & $\%$ Leaves $^{\mathrm{a}}$ & $\%$ Stems & $\mathrm{REF}^{\mathrm{b}}$ \\
\hline Phaseolus vulgaris & Bean & Fabaceae & Main crop & $43 \pm 3.1$ & $57 \pm 3.7$ & 1 \\
\hline Glycine $\max$ & Soybean & Fabaceae & Main crop & $38 \pm 3.2$ & $62 \pm 2.1$ & 2 \\
\hline Zea mays & Maize & Poaceae & Main crop & $26 \pm 3.6$ & $74 \pm 3.9$ & 3 \\
\hline Helianthus annuus & Sunflower & Asteraceae & Main crop & $39 \pm 4.2$ & $61 \pm 5.1$ & 4 \\
\hline Crotalaria juncea & Sunn hemp & Fabaceae & Cover crop & $19 \pm 2.3$ & $81 \pm 4.6$ & 5 \\
\hline Canavalia ensiformis & Jack bean & Fabaceae & Cover crop & $72 \pm 4.9$ & $28 \pm 3.8$ & 6 \\
\hline Stizolobium niveum & Gray mucuna & Fabaceae & Cover crop & $42 \pm 3.6$ & $58 \pm 2.9$ & 7 \\
\hline Pennisetum glaucum & Millet & Poaceae & Cover crop & $32 \pm 4.1$ & $68 \pm 2.5$ & 8 \\
\hline Sorghum bicolor & Sorghum & Poaceae & Main crop & $55 \pm 3.5$ & $45 \pm 4.3$ & 9 \\
\hline Crotalaria spectabilis & Showy rattlebox & Fabaceae & Cover crop & $30 \pm 3.1$ & $70 \pm 3.1$ & 10 \\
\hline Avena strigosa & Black oat & Poaceae & Cover crop & $48 \pm 2.0$ & $52 \pm 2.7$ & 11 \\
\hline Vicia sativa & Vetch & Fabaceae & Cover crop & $62 \pm 1.8$ & $38 \pm 3.5$ & 12 \\
\hline Triticum aestivum & Wheat & Poaceae & Main crop & $42 \pm 4.1$ & $58 \pm 3.3$ & 13 \\
\hline Raphanus sativus oleiferus & Oilseed radish & Brassicaceae & Cover crop & $38 \pm 2.2$ & $62 \pm 3.3$ & 14 \\
\hline Secale cereale & Rye & Poaceae & Main crop & $29 \pm 3.1$ & $71 \pm 4.2$ & 15 \\
\hline Pisum arvensis & Pea & Fabaceae & Cover crop & $68 \pm 2.4$ & $32 \pm 2.4$ & 16 \\
\hline Triticosecale rimpaui & Triticale & Poaceae & Main crop & $44 \pm 2.8$ & $56 \pm 3.9$ & 17 \\
\hline Brassica napus oleifera & Oilseed rape & Brassicaceae & Main crop & $28 \pm 3.6$ & $72 \pm 2.8$ & 18 \\
\hline Hordeum vulgare & Barley & Poaceae & Main crop & $50 \pm 3.3$ & $50 \pm 2.0$ & 19 \\
\hline Lolium multiflorum & Ryegrass & Poaceae & Cover crop & $37 \pm 3.2$ & $63 \pm 2.9$ & 20 \\
\hline Ricinus communis & Castor bean & Euphorbiaceae & Main crop & $52 \pm 5.1$ & $48 \pm 4.4$ & 21 \\
\hline Cajanus cajan & Dwarf pigeonpea & Fabaceae & Cover crop & $34 \pm 3.2$ & $66 \pm 3.7$ & 22 \\
\hline Lupinus angustifolius & Blue lupine & Fabaceae & Cover crop & $57 \pm 2.7$ & $43 \pm 4.3$ & 23 \\
\hline Lupinus albescens & Native lupine & Fabaceae & Cover crop & $51 \pm 3.7$ & $49 \pm 4.1$ & 24 \\
\hline Oryza sativa & Rice & Poaceae & Main crop & $50 \pm 2.9$ & $50 \pm 3.4$ & 25 \\
\hline
\end{tabular}

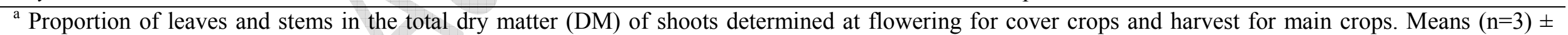
standard deviation (S.D.).

${ }^{\mathrm{b}}$ Reference. 
2.3 Soil, treatments and experimental conditions

The soil used in the incubation experiment was a Typic Hapludalf (USDA classification) collected from the $0-10 \mathrm{~cm}$ layer in the same area as the plants. This soil contained $120 \mathrm{~g} \mathrm{~kg}^{-1}$ clay, $280 \mathrm{~g} \mathrm{~kg}^{-1}$ silt, $600 \mathrm{~g} \mathrm{~kg}^{-1}$ sand, $8.7 \mathrm{~g} \mathrm{~kg}^{-1}$ organic $\mathrm{C}$ and $0.9 \mathrm{~g} \mathrm{~kg}^{-1}$ total $\mathrm{N}$, with a $\mathrm{pH}$ $\left(\mathrm{H}_{2} \mathrm{O}\right)$ of 5.4. The soil initially contained 9.4 $\mathrm{mg}$ mineral $\mathrm{N} \mathrm{kg}^{-1}$ dry soil. After visible organic residues had been removed by hand, the soil was sieved to $4 \mathrm{~mm}$. Distilled water was applied to the soil to achieve a soil moisture content of $80 \%$ of field capacity. The soil was pre-incubated in plastic bags at $25^{\circ} \mathrm{C}$ for 5 days. The experiment consisted of incubations conducted for 120 days in the dark at $25 \pm 1^{\circ} \mathrm{C}$ to measure the $\mathrm{C}$ and $\mathrm{N}$ mineralization of leaves, stems and mixtures of leaves + stems. The experimental design consisted of two sets of jars prepared and monitored in parallel, with one jar used to evaluate $\mathrm{C}$ dynamics and one to evaluate $\mathrm{N}$ dynamics. The 76 treatments consisted of a non-amended soil (as a control), soil + leaves, soil + stems and soil + mixture (leaves + stems) for the 25 plant species listed in Table 1 with three replicates per treatment and per sampling time. The treatments were arranged in a completely randomized design. For each replicate, a sample of $134 \mathrm{~g}$ of soil at $13.8 \%$ moisture (equivalent to $80 \%$ of field capacity) was used. First, a moist soil subsample (67 g) was placed in a $110-\mathrm{ml}$ cylindrical acrylic pot (5.0 $\mathrm{cm}$ in diameter and $5.0 \mathrm{~cm}$ in height) and compressed to a height of $2.5 \mathrm{~cm}$. A second soil subsample $(67 \mathrm{~g})$ was placed in the same acrylic pot and compressed to a total height of 5 $\mathrm{cm}$. Thus, the soil in each pot reached a final bulk density of $1.2 \mathrm{~g} \mathrm{~cm}^{-3}$. The residues were applied on the surface of the soil at a rate of $0.56 \mathrm{~g}$ dry matter (DM)/pot (equivalent to a basis of $4.74 \mathrm{~g} \mathrm{DM}$ per kg of dry soil or a rate of $3.06 \mathrm{Mg} \mathrm{DM} \mathrm{ha}^{-1}$ ), which was equivalent to the addition of 1790 (rice stem) to 2210 (dwarf pigeonpea leaf) $\mathrm{mg} \mathrm{C} \mathrm{kg}^{-1}$ of dry soil and 13 (sunflower stem) to 220 (gray mucuna leaf) $\mathrm{mg}$
$\mathrm{N} \mathrm{kg}^{-1}$ of dry soil. Each acrylic pot was placed in a 1000-ml glass jar prior to incubation.

\subsection{Analytical procedures}

C mineralization of the crop residue mixtures was assessed by quantifying the $\mathrm{CO}_{2}$ release. The $\mathrm{CO}_{2}$ produced in the soil was trapped in 10 $\mathrm{ml}$ of $1 \mathrm{M} \mathrm{NaOH}$ in a beaker placed inside each glass jar. The $\mathrm{NaOH}$ beakers were changed at each sampling, i.e., at 2, 4, 7, 10, 14, 21, 28, 35, 50, 70, 90 and 120 days. The carbonate trapped in the $\mathrm{NaOH}$ was precipitated with a $2 \mathrm{M} \mathrm{BaCl}_{2}$ solution, and the remaining $\mathrm{NaOH}$ was backtitrated with $1 \mathrm{M} \mathrm{HCl}$. At all sampling times, the jars were aerated for $10 \mathrm{~min}$. to renew the internal atmosphere and the soil water content was checked by weighing and adjusted as necessary. The apparent $\mathrm{C}$ mineralization of the crop residue mixtures was calculated by subtracting the amounts of $\mathrm{CO}_{2}-\mathrm{C}$ evolved from the control treatment from the amounts of $\mathrm{CO}_{2}$ $C$ evolved from the amended treatments. Apparent mineralization assumes that there is no effect of crop residue addition on soil $\mathrm{C}$ mineralization (no priming effect) or that this effect is similar regardless of the type of crop residue added.

The soil mineral $\mathrm{N}\left(\mathrm{NH}_{4}^{+}+\mathrm{NO}_{2}^{-}+\mathrm{NO}_{3}^{-}\right)$ was measured in all treatments at time 0 and at $7,14,21,35,63,90$ and 120 days of incubation. At each sampling time, the visible residue particles were removed from the soil surface. The mineral $\mathrm{N}$ was extracted from fresh soil samples with $1 \mathrm{M} \mathrm{KCl}(30 \mathrm{~min}$. shaking) and a soil:solution ratio of 1:4. The soil $\mathrm{KCl}$ suspension was settled for $30 \mathrm{~min}$. until the supernatant liquid was clear, and the mineral $\mathrm{N}$ in a soil extract aliquot was measured by steam distillation (Keeney and Nelson, 1982). The jars were opened periodically and aerated and the humidity was adjusted when necessary. The net $\mathrm{N}$ mineralization was calculated by subtracting mineral $\mathrm{N}$ in the control from the amount of mineral $\mathrm{N}$ accumulated in each amended treatment. 
Final version of manuscript published in: Soil Biology and Biochemistry, 2014, DOI 10.1016/j.soilbio.2014.07.014

Table 2: Parameters of chemical composition, $\mathrm{C}$ mineralization and $\mathrm{N}$ mineralization of different types of residues used in this study (minimum, maximum and mean values).

\begin{tabular}{|c|c|c|c|c|c|c|c|c|c|}
\hline \multirow{2}{*}{ Parameter } & \multicolumn{3}{|c|}{ Leaves } & \multicolumn{3}{|c|}{ Stems } & \multicolumn{3}{|c|}{ Mixture } \\
\hline & Min. & Max. & Mean & Min. & Max. & Mean & Min. & Max. & Mean \\
\hline \multicolumn{10}{|l|}{ Chemical fraction $\left(\mathrm{g} \mathrm{kg}^{-1} \mathrm{DM}\right)$} \\
\hline $\mathrm{SOL}^{\mathrm{a}}$ & 167 & 817 & 546 & 111 & 442 & 249 & 141 & 585 & 373 \\
\hline HEM & 3 & 406 & 143 & 60 & 331 & 197 & 60 & 323 & 170 \\
\hline CEL & 139 & 443 & 258 & 351 & 614 & 452 & 243 & 511 & 375 \\
\hline LIG & 16 & 137 & 53 & 30 & 198 & 102 & 33 & 143 & 82 \\
\hline $\mathrm{C}$ & 391 & 486 & 432 & 387 & 458 & 442 & 394 & 466 & 441 \\
\hline $\mathrm{N}$ & 5.6 & 51.8 & 26.1 & 2.6 & 24.7 & 9.7 & 4.3 & 40.3 & 17.0 \\
\hline Csw & 33.1 & 326.3 & 141.6 & 28.3 & 227.8 & 83.3 & 40.8 & 252.5 & 110.3 \\
\hline Nsw & 3.4 & 35.8 & 12.6 & 1.4 & 29.3 & 6.8 & 2.9 & 34.0 & 9.5 \\
\hline POL & 4.3 & 78.2 & 30.2 & 2.8 & 17.3 & 9.6 & 6.4 & 49.8 & 20.1 \\
\hline \multicolumn{10}{|l|}{$\mathrm{C}$ and $\mathrm{N}$ mineralization } \\
\hline$C_{0}^{\mathrm{b}}(\%)$ & 46.9 & 64.3 & 56.0 & 25.8 & 56.9 & 46.1 & 41.1 & 60.7 & 51.0 \\
\hline$k^{\mathrm{c}}\left(\right.$ day $\left.^{-1}\right)$ & 0.022 & 0.128 & 0.063 & 0.012 & 0.109 & 0.039 & 0.021 & 0.104 & 0.050 \\
\hline $\mathrm{C} \min 120 \mathrm{~d}(\%$ added $\mathrm{C})$ & 43.9 & 67.1 & 58.0 & 26.0 & 61.5 & 46.7 & 39.4 & 63.4 & 52.6 \\
\hline Net $\mathrm{N} \min 120 \mathrm{~d}\left(\mathrm{mg} \mathrm{N} \mathrm{kg}^{-1}\right.$ soil $)$ & -20.0 & 140.8 & 45.3 & -38.0 & 52.7 & -7.7 & -26.3 & 79.1 & 13.1 \\
\hline
\end{tabular}

${ }^{a}$ SOL: Soluble fraction (Van Soest); HEM: Hemicellulose; CEL: Cellulose; LIG: Lignin; C: Total organic carbon; N: Total nitrogen; Csw: Water-soluble carbon; Nsw: Water-soluble nitrogen; POL: Soluble polyphenols; DM: Dry matter.

${ }^{\mathrm{b}}$ Potentially mineralizable $\mathrm{C}$ pool.

${ }^{\mathrm{c}}$ Mineralization constant rate. 


\subsection{Analytical procedures}

Data of $\mathrm{N}$ mineralization and of cumulative mineralized $\mathrm{C}$ measured over 120 days were analyzed by one-way analysis of variance. Least significant difference tests $(\mathrm{P}<0.05)$ were used to determine whether significant differences occurred.

To obtain a quantitative measure of the relative importance of the initial chemical characteristics of residues in determining residue mineralization, we first calculated $\mathrm{C}$ mineralization using an exponential equation according to Jung et al. (2011) as follows:

$$
\operatorname{Cmin}=C_{0}\left(1-e^{-k \text { day }}\right)
$$

where $C \min$ is the amount of mineralized $\mathrm{C}, C_{0}$ is the potentially mineralizable $\mathrm{C}$ pool, $k$ is a mineralization constant and day is the incubation period. Stepwise multiple regression analysis was then used to determine which combinations of chemical variables best explained the variations in $C_{0}$ and $k$. Only those variables that were found to be significant at $\mathrm{P}<0.05$ were retained in the regressions. Regressions were performed with all available chemical variables of residues.

A principal component analysis (PCA) was also performed to investigate the chemical traits that differentiate plant organs and plant families according to Aulen et al. (2012). PCA was performed on the correlation matrix obtained from the proximate analysis (i.e., SOL, CEL, HEM and LIG), C, N, watersoluble fractions (i.e., Csw and Nsw) and POL. The potentially mineralizable $\mathrm{C}$ pool $\left(C_{0}\right)$ and the mineralization constant $(k)$ were added as supplementary variables (i.e., not included in the ordination of species) to analyze their relationships with chemical characteristics. The PCA produced an ordination of the species and the chemical composition of the leaves, stems and mixtures, which were plotted in one and two dimensions, respectively, based on the scores of the first two principal components (PCs). A correlation circle was computed to assess the importance of each chemical component in the PC axes. We considered $r$ values (i.e., the correlation coefficient) as significant contributors when $r \geq 0.5$ (Guénon et al., 2013).

To address the question of the nonadditivity of mineralization in residue mixtures, we compared the evolved $\mathrm{CO}_{2}$, soil mineral $\mathrm{N}$ content and net $\mathrm{N}$ mineralization in residue mixture treatments ('observed') to the 'expected' values for each crop species. The expected $\mathrm{C}-\mathrm{CO}_{2}$ mineralized from crop residue mixtures at days 14 and 120 was calculated as the weighted mean of the evolved leaf-derived $\mathrm{C}-\mathrm{CO}_{2}$ and stem-derived $\mathrm{C}-\mathrm{CO}_{2}$ according to their respective proportions in the mixture (Table 1). This procedure assumes an additive effect of mixing the two types of residues. A similar calculation was performed for the net mineralization of $\mathrm{N}$. The calculated values were compared to the observed values, and differences were analyzed using Tukey's test. Based on the results of the statistical analysis, it was possible to classify residue interactions for $\mathrm{C}$ and $\mathrm{N}$ mineralization into 3 types as follows (Robinson et al., 1999): (1) measured and expected values do not significantly differ, and the contribution of each residue type to the mixture is additive; (2) measured values are significantly greater than expected values, indicating that mixing the residues has a positive (or synergistic) effect; and (3) measured values are significantly lower than expected values, indicating that mixing the residues has a negative effect (or antagonistic) on mineralization.

Deviation from additivity (Da) was calculated using the signed non-additivity calculation according to Makkonen et al. (2013) as follows:

$$
\mathrm{Da}=\left(\frac{\text { Observed CO2 (or Nmin) }}{\text { Expected CO2 (or Nmin) }}\right)-1
$$

We used a multiple-trait-similarity measure to characterize differences in the chemical traits (composition) of the leaf and stem residues of each mixture for each species (De Bello et al., 2013) and to assess the effect 
of similarity in functional traits on nonadditive effects. According to Gower and Legendre (1986) and Pavoine et al. (2009), we used Gower's (1971) general coefficient of similarity applied to quantitative variables with only positive and no missing values. The similarity between leaf residue $i$ and stem residue $j$ for a variable $k$ is measured as the difference between different traits, and this difference is standardized between 0 and 1 for each trait as follows:

$$
\mathrm{S}_{\mathrm{ijk}}=1-\left|\mathrm{X}_{\mathrm{ik}}-\mathrm{X}_{\mathrm{jk}}\right| / \mathrm{R}_{\mathrm{k}}
$$

where $\mathrm{S}_{\mathrm{ijk}}$ is the similarity between residue $i$ and residue $j$ calculated for the $k$ the variable; $X_{k}$ is the measured variable; and $X_{i}$ and $X_{j}$ are the values taken by the $X_{k}$ variable of residues $i$ and $j$, respectively; and $\mathrm{R}_{\mathrm{k}}$ is the range of $\mathrm{X}_{\mathrm{k}}$ variables measured. In this work, $R_{k}$ was taken for each variable as the maximal difference between all values of the variable in the entire population ( 25 species) as follows:

$$
\mathrm{R}_{\mathrm{k}}=\operatorname{Max}\left(\mathrm{X}_{\mathrm{ik}}-\mathrm{X}_{\mathrm{jk}}\right)
$$

As the leaf:stem ratio in the mixtures were not 50:50 but, rather, depended on the leaf:stem ratios in the field, $S_{i j k}$ was weighted according to the proportion of the two plant parts in the mixture. The values of $S_{i j k}$ and $S_{i j}$ lie in the interval of 0 to 1 . In the present study, the so-called 'species' of the original method were leaf and stem, and the data set included 25 pairs of leaves and stems (corresponding to the 25 plant species studied) and 9 variables corresponding to the chemical characteristics (or traits) measured. The relationships between the average additivity value and the single-trait similarity $\left(\mathrm{S}_{\mathrm{ijk}}\right)$ were analyzed by linear regression. The traits that showed significant regressions with additivity for $\mathrm{C}$ or for $\mathrm{N}$ were selected to build the multiple trait similarity coefficients $\left(\mathrm{S}_{\mathrm{ij}}\right)$.

\section{Results}

3.1 Chemical quality of leaves, stems and mixtures

The parameters of the chemical composition (minimum, maximum and mean values) of leaves, stems and mixtures (leaf + stem) of the 25 plant species are summarized in Table 2. The residue $\mathrm{C}$ and $\mathrm{N}$ contents ranged from 387 to $486 \mathrm{~g} \mathrm{~kg}^{-1}$ and from 2.6 to $51.8 \mathrm{~g} \mathrm{~kg}^{-1}$, respectively, resulting in a $\mathrm{C}: \mathrm{N}$ ratio ranging from 8.6 to 178 . The measured chemical compositions of the residue mixtures were close $\left(r^{2} \geq 0.96\right)$ to the expected chemical composition (data not shown). The chemical characteristics were analyzed by a PCA to extract the most significant differences between organs and species (Fig. 1). The PCA showed that the first two PCs accounted for $70 \%$ of the total variance of the data. PC 1 explained $55 \%$ of the variance of the data and separated leaves of Fabaceae and Poaceae species as follows: in the positive part of the PCA, leaves from Poaceae species were most strongly correlated with CEL $(r=+0.91)$ and HEM ( $r=+0.76)$ contents; and in the negative part of the PCA, leaves from Fabaceae species were most strongly correlated with SOL, total $\mathrm{N}$, POL and water-soluble fractions (in the range of $r=-0.65$ to -0.97 ) (Fig. 1a, c). PC 2 explained $15 \%$ of the variance of the data and separated stems of Poaceae from those of other families (Fabaceae, Asteraceae, Brassicaceae and Euphorbiaceae) as follows: in the negative part of the PCA, stems from Poaceae species were slightly correlated with HEM content $(\mathrm{r}=-$ 0.32 ) and stems from other families were correlated with LIG content ( $\mathrm{r}=+0.78)$ (Fig. 1a, b, c). The mixture (leaf + stem) (Fig. 1a) showed an intermediate distribution between leaves and stems for PC 1 and PC 2, as expected. When analyzed only according to botanical families (Fig. 1b, c), PC 1 clearly showed that all residues from Poaceae species (stems, leaves and mixtures) were close to each other and were strongly correlated with CEL $(\mathrm{r}=+0.91)$ and HEM $(\mathrm{r}=+0.76)$ contents. Conversely, the distribution of residues from 
Fabaceae species was much wider along the two axes.
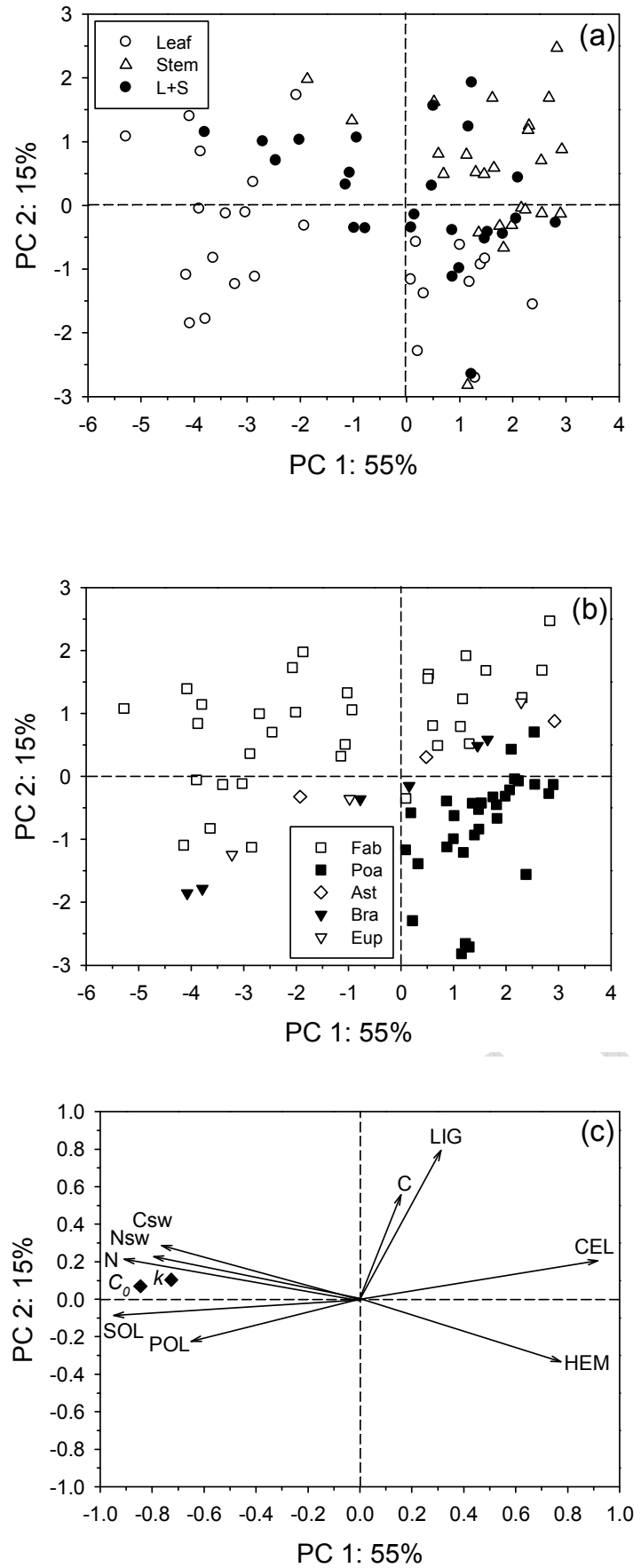

Fig. 1: Factorial map (PC $1 \times$ PC 2) (a, b) and correlation circle (c) obtained from principal component analysis (PCA) performed on biochemical properties (i.e., Van Soest fractions, total $\mathrm{N}$, total $\mathrm{C}$, total $\mathrm{N}$, watersoluble fractions and polyphenols) of leaves, stems and mixtures of leaves + stems $(\mathrm{L}+\mathrm{S})$. Mineralization constant $(k)$ and mineralizable
$\mathrm{C}$ pool $\left(C_{0}\right)$ were added as supplementary variables, i.e., not included in the ordination of species. Fab: Fabaceae; Poa: Poaceae; Ast: Asteraceae; Bra: Brassicaceae; Eup: Euphorbiaceae.

Similarity coefficients for each individual chemical characteristic and aggregated similarity coefficients expressed the extent of differences among the chemical traits of leaves and stems for each species. Varied conditions occurred in this study. For example, sunn hemp and oilseed radish exhibited the widest variation in chemical composition between leaves and stems $\left(\mathrm{S}_{\mathrm{ij}}=0.28\right)$, and rice exhibited a close composition in leaves and stems for all criteria $\left(S_{i j}=0.93\right)$ (Supplementary data $\left.A\right)$. As expected from the PCA, the similarity coefficients also effectively expressed the differences between families, with $\mathrm{S}_{\mathrm{ij}}=0.46 \pm 0.12$ for Fabaceae and $\mathrm{S}_{\mathrm{ij}}=0.81 \pm 0.20$ for Poaceae. Other families (represented by one or two species; i.e., Brassicaceae, Euphorbiaceae and Asteraceae) had a low $\mathrm{S}_{\mathrm{ij}}$ value, indicating a large difference in the chemical traits between stems and leaves. The 'weighted' similarity coefficients reflected the actual contribution of leaves and stems to chemical traits by taking into account their actual proportion in mixtures. The range of (weighted) $\mathrm{S}_{\mathrm{ij}}$ values was narrowed and varied from 0.44 (pea) to 0.96 (rice) (Supplementary data $B$ ). The average weighted $S_{i j}$ changed to $0.60 \pm 0.09$ for Fabaceae species, but it remained unchanged for Poaceae species $(0.81 \pm 0.16)$ because of the similarity of the chemical composition of the leaves and stems of Poaceae mixtures.

\section{2 $\mathrm{C}$ and $\mathrm{N}$ mineralization}

The cumulative $\mathrm{C}$ and $\mathrm{N}$ mineralization in soils amended with leaves, stems and mixtures varied widely among species (Fig. 2). The cumulative apparent $\mathrm{C}$ mineralization at day 120 ranged from $44 \pm 1.0$ to $67 \pm 2.2 \%$ added $C$ for leaves (Fig. 2a), $26 \pm 2.8$ to $62 \pm 2.7 \%$ added $\mathrm{C}$ for stems (Fig. 2c) and $39 \pm 1.8$ to $63 \pm 1.7 \%$ 
added $\mathrm{C}$ for the mixtures (Fig. 2e). The net $\mathrm{N}$ mineralization in soil showed a contrasting pattern among residue types in different species. Most of the leaf treatments induced a net increase in soil mineral $\mathrm{N}(+141$ to $-20 \mathrm{mg}$ $\mathrm{N} \mathrm{kg}^{-1}$ soil at day 120) (Fig. 2b), but stem decomposition induced stronger $\mathrm{N}$ immobilization, with net mineralization in the range of +53 to $-38 \mathrm{mg} \mathrm{N} \mathrm{kg}^{-1}$ soil at day 120 (Fig. 2d). As expected, the mixtures generated intermediate results ( +79 to $-26 \mathrm{mg} \mathrm{N} \mathrm{kg}^{-1}$ soil) (Fig. 2f, Table 2). In several conditions, the mineral $\mathrm{N}$ content in soil was almost depleted during the first 14 days and remained depleted until the end of incubation (day 120), as observed for residues of maize (3), rye (15) and barley (19) species (Fig. 2b, d, f). The net $\mathrm{N}$ mineralization at day 120 was positively and linearly related to the residue $\mathrm{N}$ concentrations, with residue with low $\mathrm{N}$ content $\left(<12.4 \mathrm{~g} \mathrm{~N} \mathrm{~kg}^{-}\right.$ ${ }^{1}$ residue $\mathrm{DM}$ or $\mathrm{C}: \mathrm{N}$ ratio $>35.2$ ) inducing a net immobilization (Fig. 3). 

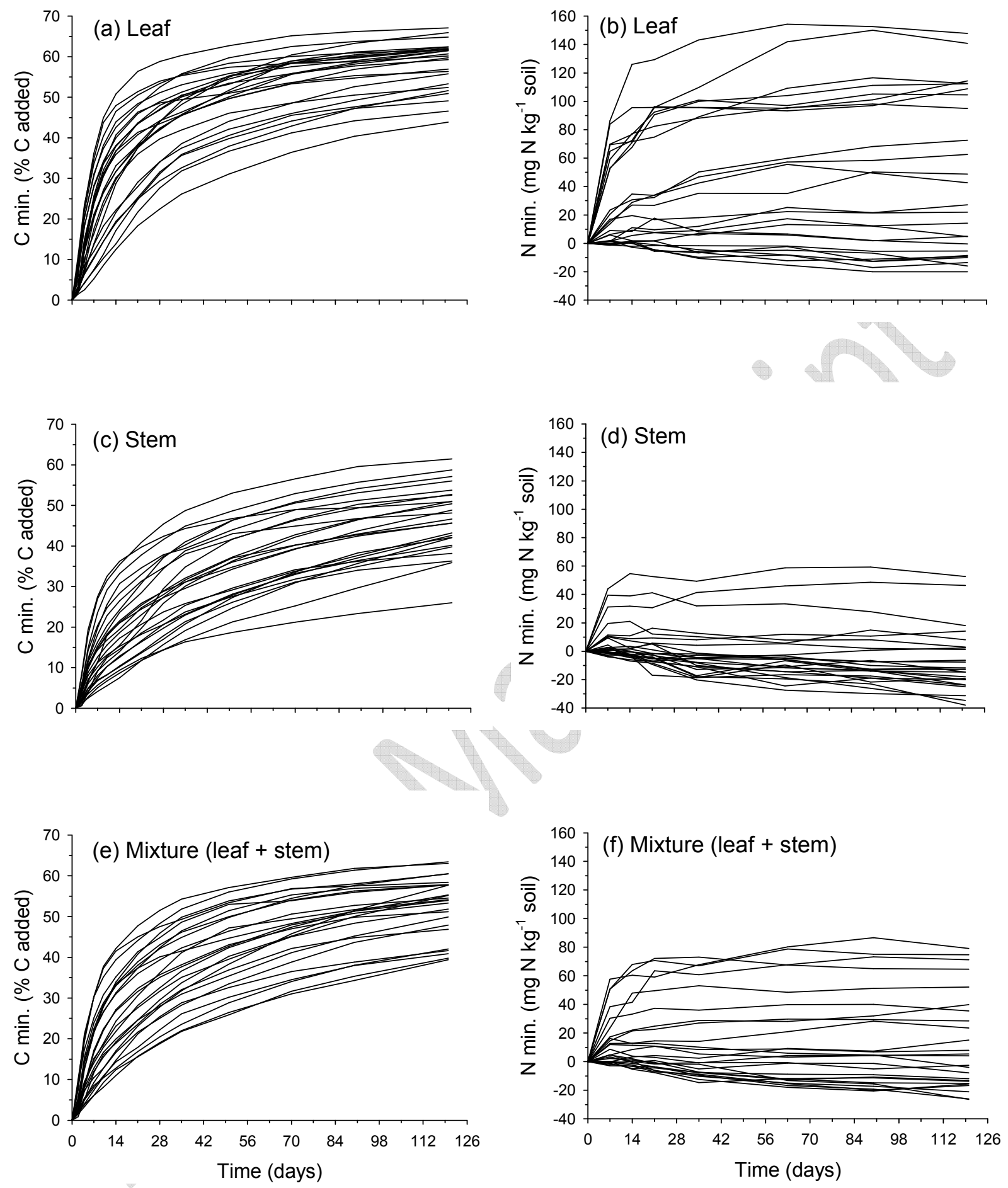

Fig. 2: Cumulative $\mathrm{CO}_{2}$ mineralization ( $(a, c, e)$ and net changes in soil mineral $\mathrm{N}$ contents $(b, d, f)$ for leaves, stems and mixtures (leaf + stem) during decomposition in soil at $25^{\circ} \mathrm{C}$ for 120 days. Net mineralization was calculated by the difference between amended and non-amended control treatments. Values are the mean of 3 replicates. 


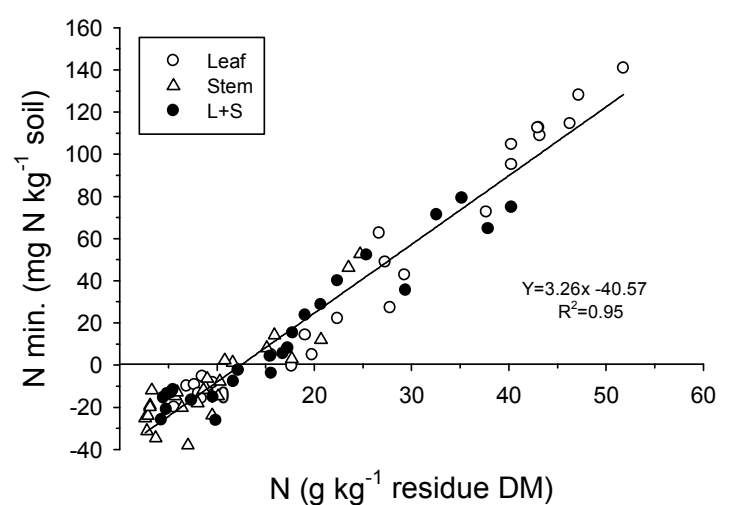

Fig. 3: Relationships between net $\mathrm{N}$ mineralized in soil after 120 days of incubation and initial total $\mathrm{N}$ content in the dry matter (DM) of the leaves, stems and mixtures of leaves + stems $(\mathrm{L}+\mathrm{S})$ for 25 crop species. Line indicate the $95 \%$ confidence intervals for the difference of means $(\mathrm{P}<0.001)$.

The $C_{0}$ of residues represented, on average, $46.1 \%$ added $\mathrm{C}$ for stems and $56.0 \%$ added $\mathrm{C}$ for leaves, and these values were close to the observed cumulative $\mathrm{C}$ mineralized at day 120 (Table 2). As expected, the mineralization constant $(k)$ of the $\mathrm{C}_{0}$ differed among residues and ranged from 0.012 (sunflower stem) to 0.128 (oilseed radish leaf) (Table 2; Supplementary data C). The PCA analyses indicated that total $\mathrm{N}$, total soluble polyphenols and soluble fractions (Van Soest; water-soluble $\mathrm{N}$ and $\mathrm{C}$ ) were correlated with a high $C_{0}$ and with $k$ when considering all residues (stems, leaves and mixtures) (Fig. 1c). But the relationships between $k$ or $C_{0}$ and the initial residue chemical composition varied greatly according to plant organ (leaf vs. stem vs. mixture) and to the range of species considered (Table 3). N content was the greatest explanatory chemical trait for leaves $\left(r^{2} \geq 0.78\right)$, which was not the case for stems, for which HEM and/or CEL were more significant $\left(r^{2} \geq 0.42\right)$. The LIG content was never selected, except for $k$ in mixtures and Poaceae stems $\left(r^{2} \geq 0.66\right)$. All of the equations were highly significant $(\mathrm{P}<0.001)$.
3.3 Interactions between leaves and stems in mixtures

The relationship between observed and expected mineralization was analyzed using residue $\mathrm{C}$ mineralization and soil $\mathrm{N}$ content at days 14 (early decomposition) and 120 (end of incubation) and also expressed by signed noadditivity calculation (Da). Most of the statistically significant differences observed at day 120 had been previously obtained at day 14 for C and N (Supplementary data D), and the results discussed here are values obtained after 120 days of incubation. Overall, the effect of mixing residues was low for $\mathrm{C}$ mineralization (Fig. 4a; Supplementary data D) with the following significant effects: additive for 15 mixtures, positive for 7 mixtures and negative for 3 mixtures. The positive or synergistic effect (mean $+9 \%$ added $\mathrm{C}$ mineralized) occurred with mixtures of sunflower (4), vetch (12), wheat (13), oilseed radish (14), oilseed rape (18), ryegrass (20) and dwarf pigeonpea (22). The negative or antagonistic effect (mean $-5 \%$ added $\mathrm{C}$ mineralized) occurred with mixtures of bean (1), showy rattlebox (10) and rye (15). Da varied in the range -0.1 to +0.2 .

The effects of mixing on soil mineral $\mathrm{N}$ content differed from the effect on $\mathrm{C}$ mineralization with the following significant effects: additive for 18 species; positive for 2 mixtures (mean $+7.8 \mathrm{mg} \mathrm{N} \mathrm{kg}^{-1}$ soil), i.e., showy rattlebox (10) and castor bean (21); and negative for 5 mixtures (mean $-16.5 \mathrm{mg} \mathrm{N} \mathrm{kg}^{-1}$ soil), i.e., jack bean (6), gray mucuna (7), vetch (12), pea (16) and dwarf pigeonpea (22) (Fig. $4 \mathrm{~b}$; Supplementary data D). All Poaceae mixtures showed additive effects for mineralized $\mathrm{N}$ in soil, as the observed deviations from additivity were not significant (Fig. 4b). Da varied in the range -0.2 to +0.2 . For most of the species, a non-additive effect of mixing on $\mathrm{C}$ mineralization was not associated with a non-additive effect on $\mathrm{N}$ mineralization. 

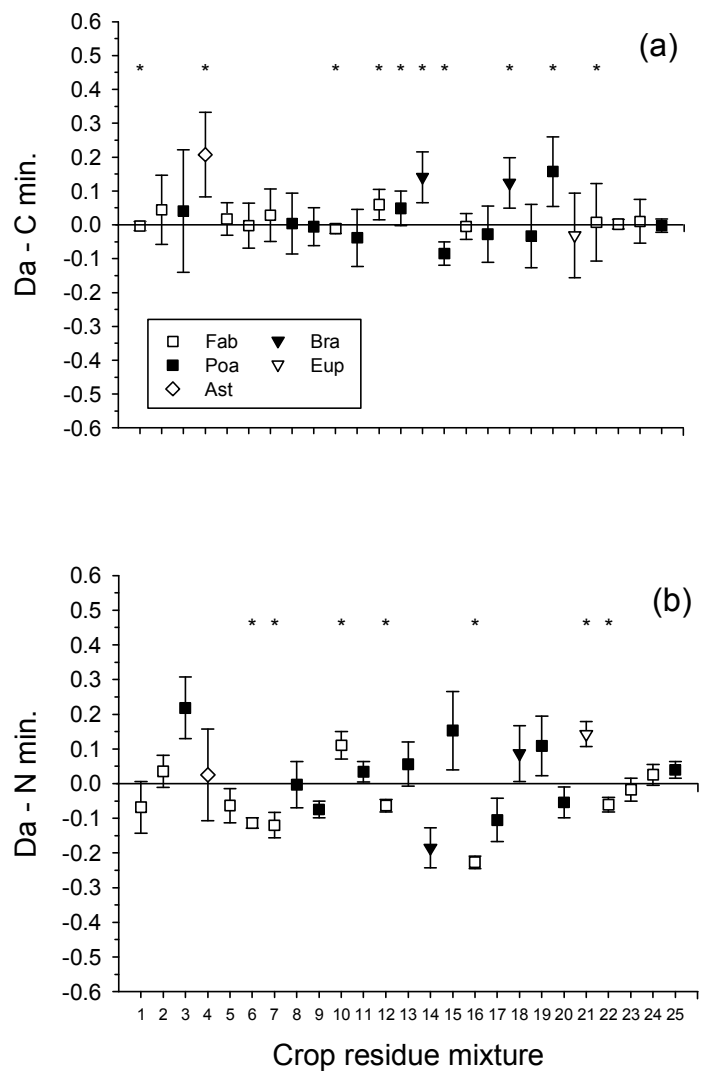

Fig. 4: Average deviation from additivity (Da) calculated for $\mathrm{C}$ mineralized in residue (a) and net $\mathrm{N}$ mineralization in soil (b) in 25 litter mixtures. Asterisks indicate significant difference of means according to Tukey's test $(\mathrm{P}<0.05)$. Fab: Fabaceae; Poa: Poaceae; Ast: Asteraceae; Bra: Brassicaceae; Eup: Euphorbiaceae. See Table 1 for the litter mixture species studied. Bars indicate the standard deviation of the means for mineralized $\mathrm{C}$ and $\mathrm{N}$.

We also analyzed the mixtures all together (Fig. 5). There was a significant linear correlation between observed and expected $\mathrm{C}$ mineralization for the 25 mixtures $(\mathrm{Y}=1.02 \mathrm{x}$; $\mathrm{r}^{2}=0.81 ; \mathrm{P}<0.05$ ) (Fig. 5a) showing that on average there was no interaction for $\mathrm{C}$ mineralization. Mixtures with a cumulative $\mathrm{C}$ mineralization $>\sim 1000 \mathrm{mg} \mathrm{C}-\mathrm{CO}_{2} \mathrm{~kg}^{-1}$ soil exhibited really a ratio (observed:expected) close to 1 . These mixtures were mainly of Fabaceae species. For most of the mixtures with cumulative mineralization $<\sim 1000 \mathrm{mg} \mathrm{C}$ -
$\mathrm{CO}_{2} \mathrm{~kg}^{-1}$, the observed $\mathrm{C}$ mineralization differed more from the expected mineralization and was either higher or lower depending on the species. These mixtures were primarily of Poaceae species. Regarding soil N, there was also a significant linear correlation between observed and expected net $\mathrm{N}$ mineralization at day 120 ( $\mathrm{Y}=0.85 \mathrm{x} ; \mathrm{r}^{2}=0.94 ; \mathrm{P}<0.05$ ) (Fig. 5b) indicating that on average the observed net mineralization was $15 \%$ lower than the expected one. The results were confirmed when $\mathrm{N}$ mineralization values (observed or expected) were normalized, i.e., expressed in $\mathrm{N}$ mineralized per $\mathrm{g}$ of $\mathrm{C}$ mineralized for each mixture, to take into account possible differences in decomposition $(\mathrm{Y}=0.86 \mathrm{x}$; $\mathrm{r}^{2}=0.95 ; \mathrm{P}<0.05$ ).
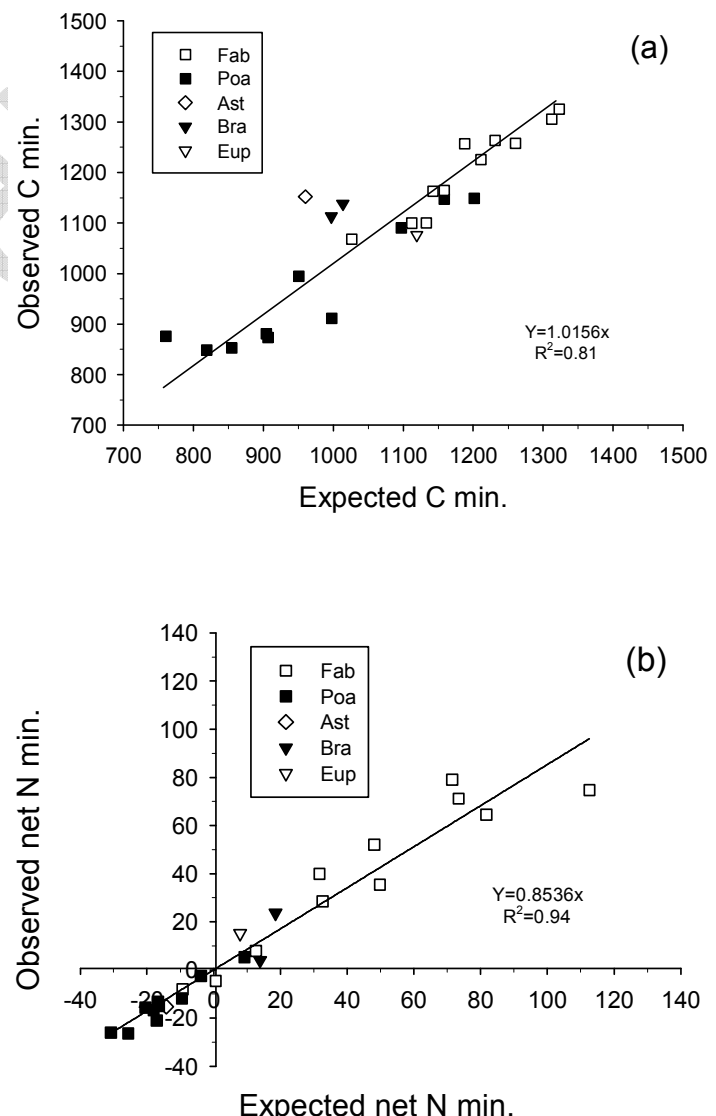

Fig. 5: Observed vs. expected $\mathrm{C}$ mineralization (mg C- $\mathrm{CO}_{2} \quad \mathrm{~kg}^{-1}$ soil) (a) and net $\mathrm{N}$ mineralization (mg N kg-1 soil) (b). Fab: Fabaceae; Poa: Poaceae; Ast: Asteraceae; Bra: Brassicaceae; Eup: Euphorbiaceae. 
The effect of similarity in functional traits on non-additive effects was analyzed by linear regression between $\mathrm{Da}$ and $\mathrm{S}_{\mathrm{ij}}$ for the 25 mixtures. Da for $\mathrm{C}$ mineralization was related neither to any single-trait similarity coefficient nor to the full aggregated similarity coefficient (data not shown). For $\mathrm{N}$ mineralization, Da was slightly but significantly related to total $\mathrm{N}$, water-soluble N, Van Soest SOL and watersoluble C (data not shown). The best relationship was obtained using only soluble $\mathrm{N}$ $\left(\mathrm{r}^{2}=0.25 ; \mathrm{P}<0.01\right)$. Da increased (from negative values to positive values) with increasing weighted $S_{\mathrm{ijk}}$ for total $\mathrm{N}$, indicating that synergistic effects on $\mathrm{N}$ mineralization occurred with decreasing heterogeneity in the $\mathrm{N}$ content of the mixtures $\left(\mathrm{r}^{2}=0.24 ; \mathrm{P}<0.01\right)$. Using only the 7 species that had a significant non-additive effect on net $\mathrm{N}$ mineralization (6 Fabaceae and one Euphorbiaceae), we observed that Da was negatively related with the $\mathrm{N}$ content of the mixtures (Fig. 6a) and positively related to $S_{\mathrm{ij}}$ for total $\mathrm{N}$ (Fig. $6 \mathrm{~b}$ ).

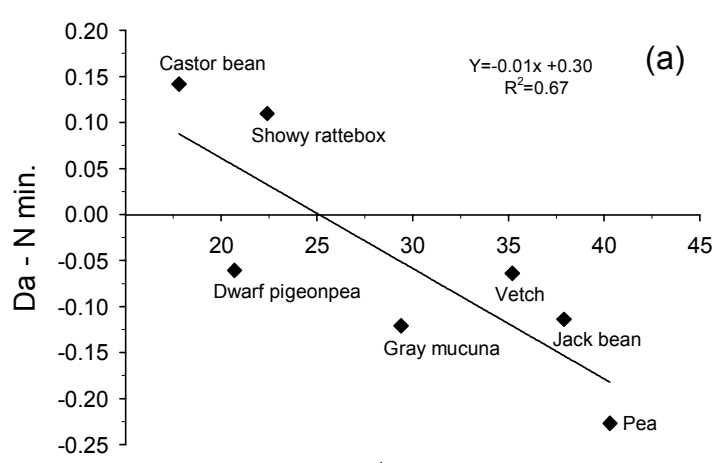

$\mathrm{N}\left(\mathrm{g} \mathrm{kg}^{-1}\right.$ residue DM)

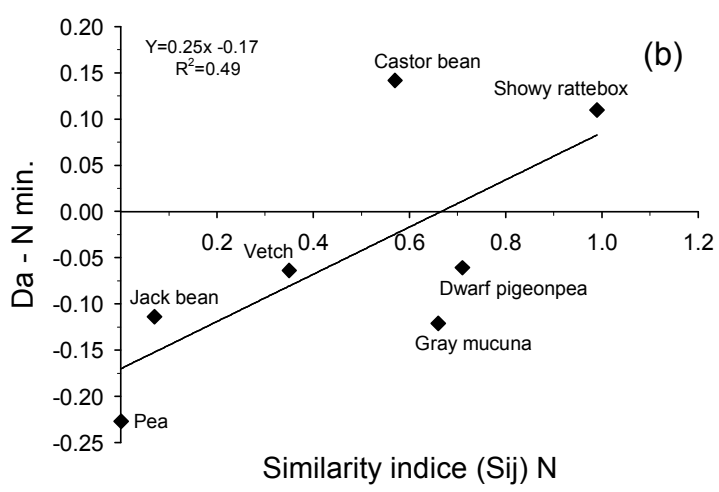

Fig. 6: Relationships between deviations from additivity (Da) calculated for net $\mathrm{N}$ mineralization and (a) mixture initial total $\mathrm{N}$ and (b) mixture heterogeneity coefficient of similarity for total $\mathrm{N}\left(\mathrm{S}_{\mathrm{ij}}\right)$. The relationship was established for 7 mixtures (leaf + stem) showing significant synergistic (positive $\mathrm{Da}$ ) or antagonistic (negative $\mathrm{Da}$ ) non-additive effects for $\mathrm{N}$ mineralization. $\mathrm{S}_{\mathrm{ij}}$ for total $\mathrm{N}$ was a similarity coefficient calculated according to Gower and Legendre (1986). 
Final version of manuscript published in: Soil Biology and Biochemistry, 2014, DOI 10.1016/j.soilbio.2014.07.014

Table 3: Multiple regression analyses with the relationships between $\mathrm{C}$ mineralization and the chemical composition of residues.

\begin{tabular}{|c|c|c|c|c|c|}
\hline Residue & & $k\left(\text { day }^{-1}\right)^{b}$ & $\mathrm{r}^{2 \mathrm{c}}$ & $C_{o}(\%)^{\mathrm{d}}$ & $\mathrm{r}^{2}$ \\
\hline \multirow[t]{3}{*}{ Leaf } & $\mathrm{All}^{\mathrm{a}}$ & $+0.57 \mathrm{~N}-0.49 \mathrm{Csw}+0.80 \mathrm{Nsw}$ & $0.78 * * *$ & $+0.73 \mathrm{~N}$ & $0.79 * * *$ \\
\hline & Fabaceae & $-2.15 \mathrm{SOL}-0.82 \mathrm{HEM}-1.64 \mathrm{CEL}+1.04 \mathrm{~N}+1.18 \mathrm{POL}$ & $0.91 * * *$ & -1.23 HEM $-0.88 \mathrm{CEL}+0.41 \mathrm{~N}+1.10 \mathrm{Csw}$ & $0.95 * * *$ \\
\hline & Poaceae & -0.28 HEM -0.45 CEL $+0.61 \mathrm{~N}$ & $0.97 * * *$ & $+0.69 \mathrm{SOL}$ & $0.78 * * *$ \\
\hline \multirow[t]{3}{*}{ Stem } & All & -0.32 HEM $-0.40 \mathrm{CEL}+0.52 \mathrm{~N}$ & $0.80 * * *$ & $+0.54 \mathrm{CEL}+0.76 \mathrm{Csw}$ & $0.42 * * *$ \\
\hline & Fabaceae & $+0.84 \mathrm{SOL}$ & $0.70 * * *$ & $+1.76 \mathrm{SOL}+1.34 \mathrm{CEL}$ & $0.60 * * *$ \\
\hline & Poaceae & $-0.81 \mathrm{LIG}$ & $0.66 * * *$ & $+0.68 \mathrm{Csw}$ & $0.46^{* * *}$ \\
\hline \multirow[t]{3}{*}{ Mixture } & All & -0.80 HEM - 0.48 CEL -0.30 LIG & $0.78 * * *$ & $+0.74 \mathrm{~N}$ & $0.54 * * *$ \\
\hline & Fabaceae & -0.73 HEM & $0.53 * * *$ & -0.63 HEM -1.1 CEL -0.95 POL & $0.87 * * *$ \\
\hline & Poaceae & $+0.90 \mathrm{~N}$ & $0.82 * * *$ & $+0.71 \mathrm{~N}$ & $0.92 * * *$ \\
\hline
\end{tabular}

${ }^{\mathrm{a}}$ Residues from 5 botanical families (Fabaceae, Poaceae, Brassicaceae, Asteraceae and Euphorbiaceae).

${ }^{\mathrm{b}}$ Mineralization constant rate.

${ }^{\mathrm{c}}$ Coefficient of determination. $* * * \mathrm{P}<0.001$

${ }^{\mathrm{d}}$ Potentially mineralizable $\mathrm{C}$ pool. 


\section{Discussion}

The main objective of this study was to quantify the effect of mixing crop residues having different chemical qualities on their decomposition and on the net $\mathrm{N}$ mineralization in the soil. The chemical quality of mixtures can be characterized by the average chemical composition and by the degree of chemical heterogeneity of the mixture, as has been discussed by Harguindeguy et al. (2008). We obtained a large range of average chemical quality by using mixtures of leaves and stems from 25 different species, primarily including Fabaceae (legumes) and Poaceae (Gramineae). The mixtures resulted in different chemical compositions both between species for the same organ (leaf or stem) and between leaves and stems for a given species. For example, most Fabaceae species (legumes) were collected in the vegetative phase and were characterized by high levels of $\mathrm{N}$ and soluble compounds. Conversely, most grass species were harvested at maturity, and their tissues were richer in cellulose, hemicellulose and lignin, as expected (Bertrand et al., 2009). The striking result is the relatively low diversity of the chemical composition among Poaceae species and between leaves and stems for a given Poaceae species, and greater diversity for the Fabaceae species.

We used the Gower coefficient of similarity proposed by Gower and Legendre (1986) and De Bello et al. (2013) to quantify the chemical heterogeneity of mixtures. The results confirmed the marked typology observed with the PCA analysis, based on the botanical family to which the species belonged $\left(\mathrm{S}_{\mathrm{ij}}=0.4\right.$ for Fabaceae and $\mathrm{S}_{\mathrm{ij}}=0.8$ for Poaceae mixtures), and the results identified species for which both organs were similar in all measured traits (e.g., $\mathrm{S}_{\mathrm{ij}}=0.93$ for rice) or different (e.g., $\mathrm{S}_{\mathrm{ij}}=0.28$ for oilseed radish). Given the characterizations, it is understandable that mixtures with low heterogeneity (mainly Poaceae mixtures in this study) suffered little or no effect of the mixing of leaves and stems, as has been observed especially for $\mathrm{N}$ mineralization. However, this study was limited to the examination of chemical features and did not account for differences in physical properties, which can also change the decomposition of residues left on the surface of the soil. This is the case, for example, for the capacity of water retention by plant residues (Iqbal et al., 2013) or the micro environmental conditions of residues (Makkonen et al., 2013), which were shown to influence the decomposition within residue mixtures.

The C mineralization was strongly dependent on the initial chemical composition, which confirmed the findings of numerous studies on annual crops (Trinsoutrot et al., 2000; Jensen et al., 2005) and perennial crops from natural ecosystems, for which the relationship between functional traits and decomposition have been extensively studied (e.g., Berglund et al., 2012). Within the two main families, the determinants of mineralization differed: most of the leaves underwent immediate decomposition (mainly in Fabaceae species), which was related to the relatively high SOL, total N, POL and water soluble fractions in leaves, in agreement with other studies, confirming the importance of soluble fractions (mainly in early stages) associated to available $\mathrm{N}$, in plant residue decomposition (Reinertsen et al., 1984; Cobo et al., 2002; Abiven et al., 2005; Thippayarugs et al., 2008). In contrast, leaves and stems of the Poaceae family exhibited gradual decomposition, resulting in more gradual and stronger $\mathrm{N}$ immobilization than exhibited by Fabaceae species. These results can be attributed to the presence of higher cellulose and hemicellulose contents but also to low $\mathrm{N}$ content (total and soluble) combined with limited $\mathrm{N}$ availability in the soil. The lignin content did not appear to regulate the residue decomposition rates in soil as shown by the multiple regression analysis between $\mathrm{C}$ mineralized and initial chemistry (Table 3). Using 47 different crop residues, Trinsoutrot et al. (2000) also found that lignin does not explain the mineralization constant $k$. Using 
249 different above-ground residues from crops, Jensen et al. (2005) found that holocellulose (CEL + HEM) was the factor that explains the greatest variability of $\mathrm{C}$ mineralization.

But under the conditions of decomposition at the soil surface with soil having initially a low mineral $\mathrm{N}$ content, as in this experiment, we assume that the low availability of $\mathrm{N}$ in the low-N residues had also influenced the kinetics of decomposition, because the potential microbial needs for $\mathrm{N}$ were not filled by $\mathrm{N}$ derived from the residues nor by the diffusion of soil $\mathrm{N}$ towards the decomposing layer (Garnier et al., 2008). Indeed, the amount of mineral $\mathrm{N}$ in the soil under the residue layer changed dramatically over the course of the decomposition process and greatly depended on the nature of the residues. This indicates that exchanges between the residue layer and the underlying soil were effective both in terms of (i) diffusion of $\mathrm{N}$ and/or $\mathrm{C}$ from the residues to the soil, which provoked $\mathrm{N}$ accumulation or $\mathrm{N}$ immobilization and (ii) diffusion of soil $\mathrm{N}$ to the residue layer to feed $\mathrm{N}$ decomposers. Therefore, $\mathrm{N}$ content in residue tissues played an important role in the processes of decomposition and $\mathrm{N}$ mineralization, particularly with residues at the soil surface and under conditions of low soil mineral $\mathrm{N}$ availability. This result was also confirmed by the strong relationship obtained between the total $\mathrm{N}$ content of residues and the net $\mathrm{N}$ mineralization in soil at day 120 .

This study showed that the effects of mixing plant residues were different depending on the process considered: here $\mathrm{C}$ mineralization, considered as a proxy of decomposition, and net $\mathrm{N}$ mineralization which is more complex to interpret as the dynamics of soil mineral $\mathrm{N}$ content and the final $\mathrm{N}$ balance, result from different processes (decomposition and $\mathrm{N}$ release, diffusion, $\mathrm{N}$ immobilization in soil and in the residue layer). In fact, the literature shows often a synergistic effect of mixed residues on the degradation of $\mathrm{C}$, which was often measured by mass loss
(Gardner and Cardon, 2004). However, our results with $\mathrm{C}$ mineralization showed a majority of additive responses, and across the 25 species, there was no significant difference between observed and expected $\mathrm{C}$ mineralized at day 120 (Fig. 5a). It is therefore not surprising that none of the chemical similarity indices (including tissue $\mathrm{N}$ or $\mathrm{C}: \mathrm{N}$ ratio) appeared significantly related to the response (additive or non-additive) for $\mathrm{C}$ mineralization, due to the overall weak effect of mixing on $\mathrm{C}$ mineralization. This result may seem surprising but in fact corresponds to the findings of other authors (e.g., Harguindeguy et al., 2008; Makkonen et al., 2013). Therefore we conclude that the mineralization of $\mathrm{C}$ from mixtures was fairly well explained by their average initial chemical traits. This conclusion is also supported by the high coefficients of determination of the equations that we obtained by stepwise regression between indices of $\mathrm{C}$ mineralization $\left(C_{0}\right.$ and $\left.k\right)$ and chemical traits for mixtures of each botanical family. The heterogeneity of chemical traits had little or no effect on $\mathrm{C}$ mineralization of the mixtures studied.

Regarding N, Da calculated by species also showed that the non-additivity occurred only for 7 residue mixtures $(28 \%$ of the mixtures studied) and was mostly negative (5 species). This trend applied to a few Fabaceae mixtures with initial high $\mathrm{N}$ content and a great heterogeneity of the mixture for $\mathrm{N}$ content trait, and was confirmed by the regression obtained between observed and expected net $\mathrm{N}$ mineralization for the 25 mixtures. This result supports the idea of a main interaction effect of residue nutrient contents, especially $\mathrm{N}$, as has been shown in several studies (Hättenschwiler et al., 2005; Berglund et al., 2012). The fact that the negative deviation for $\mathrm{N}$ was not accompanied by a positive deviation for $\mathrm{C}$ suggests that the lower net accumulation of $\mathrm{N}$ in the soil did not correspond to an increased decomposition of the mixture. Our conclusion is that available $\mathrm{N}$ from the high $\mathrm{N}$ component of the mixture was immobilized in greater quantities by decomposer organisms growing 
on the low $\mathrm{N}$ component of the mixture, as a response to an increase availability of $\mathrm{N}$ to decomposers. Recous et al. (1995) showed with maize residues, that the $\mathrm{N}$ immobilization ratio, i.e. the amount of $\mathrm{N}$ immobilized by unit of $\mathrm{C}$ decomposed (or mineralized) could increase with increasing availability of $\mathrm{N}$ to the decomposers. An analysis of chemical characteristics of the components of the mixtures at the end of experiments but also the use of isotope tracing for $\mathrm{N}$ and $\mathrm{C}$ could help answer this question (Berglund et al., 2012) Therefore the main explanatory factors for non additivity of net $\mathrm{N}$ mineralized appeared to be the average high $\mathrm{N}$ content of the mixtures combined with a high degree of heterogeneity for this chemical trait, which enhanced the $\mathrm{N}$ immobilization. It concerned mostly the Fabaceae residues in this study. Several factors could alter the observed relationships. On the one hand we made this experiment with a single soil. In conditions of decomposition at the soil surface, the type of soil would mainly affect $\mathrm{N}$ availability (particularly the initial amount of mineral $\mathrm{N}$ and/or the amount of organic matter potentially mineralized) and the soil water properties. The diffusion of mineral $\mathrm{N}$ from the soil to the residue layer could therefore be increased in other soils, modifying the intensity of interactions for N. Also the incorporation of crop residues into the soil would increase the immobilization of $\mathrm{N}$ (Aita et al., 2012), decreasing also net $N$ mineralization. But we believe that the conclusions regarding the hierarchy of responses (average chemical composition vs. chemical heterogeneity) and the differences observed between $\mathrm{C}$ and $\mathrm{N}$ interactions would still be valid in other experimental conditions.

\section{Conclusions}

This study showed that mixtures of plant residues consisting of leaves and stems of 25 species of annual crops induced a broad range of chemical composition and chemical heterogeneity of the mixtures. With regard to the effects of the functional traits of plant litters on important functions of agroecosystems, such as $\mathrm{C}$ or $\mathrm{N}$ mineralization, the results indicated that the synergistic, antagonistic or simply additive effects of mixtures were different depending on whether the residue- $\mathrm{C}$ mineralization or the soil mineral $\mathrm{N}$ were considered. In our experimental conditions, these effects were relatively low, on average. The occurrence of non-additive or additive effects depended first on the chemical quality of the mixtures (particularly the nutrient availability, like the presence of $\mathrm{N}$ that might control $\mathrm{C}$ decomposition but also alter $\mathrm{N}$ immobilization), while the intensity and sign of interactions (positive or negative) were primarily linked to the chemical heterogeneity of the mixtures. The results suggested that the availability of mineral $\mathrm{N}$ involved in the interactions between the mixture components played an important role, confirming the results of most recent works. The characterization of mixtures according to the botanical family and the type of plant organ was appropriate for interpreting the overall composition of residues considered individually or in combination, and their effects on mineralization. The results obtained in laboratory conditions suggest that the decomposition of mixtures of crop residues on the soil surface can be fairly accurately expected from the initial chemical quality of the components of the mixtures. On the other hand, the quality of these residue mixtures, and particularly their $\mathrm{N}$ content, will more influence the net availability of $\mathrm{N}$ and this phenomenon can be increased in situations where plant residues are not incorporated into soil by plowing, as explored in this work.

\section{Acknowledgments}

This work was supported by the Brazilian government through the Conselho Nacional de Desenvolvimento Científico e Tecnológico (CNPq). The bilateral Brazilian and French collaboration was funded under the Program $\mathrm{CNPq}$ - Ciência sem Fronteiras (Process Number 401724/2012-3) -and by the INRA (The Environment \& Agronomy Division) 
during M. Redin's leave at UMR FARE in Reims, France. We also thank Dr. Nicolas Fanin for constructive discussions on the topic of mixtures.

\section{References}

Abiven, S., Recous, S., Reyes, V., Oliver, R., 2005. Mineralisation of $\mathrm{C}$ and $\mathrm{N}$ from root, stem and leaf residues in soil and role of their biochemical quality. Biology and Fertility of Soils 42, 119-128.

Aita, C., Recous, S., Cargnin, R.H.O., Da Luz, L.P., Giacomini, S.J., 2012. Impact on C and $\mathrm{N}$ dynamics of simultaneous application of pig slurry and wheat straw, as affected by their initial locations in soil. Biology and Fertility of Soils 48, 633-642.

Aulen, M., Shipley, B., Bradley, R., 2012. Prediction of in situ root decomposition rates in an interspecific context from chemical and morphological traits. Annals of Botany 109, 287-297.

Berglund, S.L., Agren, G.I., 2012. When will litter mixtures decompose faster or slower than individual litters? A model for two litters. Oikos 121, 1112-1120.

Berglund, S.L., Agren, G.I., Ekblad, A., 2013. Carbon and nitrogen transfer in leaf litter mixtures. Soil Biology \& Biochemistry 57, 341-348

Bertrand, I., Chabbert, B., Kurek, B., Recous, S., 2006. Can the biochemical features and histology of wheat residues explain their decomposition in soil? Plant and Soil 281, 291-307.

Bertrand, I., Prevot, M., Chabbert, B., 2009. Soil decomposition of wheat internodes of different maturity stages: Relative impact of the soluble and structural fractions. Bioresource Technology 100, 155-163.

Cobo, J.G., Barrios, E., Kass, D.C.L., Thomas, R.J., 2002. Decomposition and nutrient release by green manures in tropical hillside agroecosystem. Plant and Soil 240, 331-342.

De Bello, F., Vandewalle, M., Reitalu, T., Leps, J., Prentice, H.C., Lavorel, S., Sykes,
M.T., 2013. Evidence for scale-and disturbance-dependent trait assembly patterns in dry semi-natural grasslands. Journal of Ecology 101, 1237-1244.

Garnier, P., Cambier, C., Bousso, M., Masse, D., Chenu, C., Recous, S., 2008. Modelling the influence of soil-plant residue contact on carbon mineralization: Comparison of a compartmental approach and a 3D spatial approach. Soil Biology \& Biochemistry 40, 2754-2761.

Garnier, E., Navas, M-L., 2012. A traitbased approach to comparative functional plant ecology: concepts, methods and applications for agroecology. A review. Agronomy for Sustainable Development 32, 365-399.

Gartner, T.B., Cardon, Z.G., 2004. Decomposition dynamics in mixed-species leaf litter. Oikos 104, 230-246.

Gessner, M.O., Swan, C.M., Dang, C.K., McKie, B.G., Bardgett, R.D., Wall, D.H., Hättenschwiler, S., 2010. Diversity meets decomposition. Trends in Ecology and Evolution 25, 372-380.

Gower, J.C., 1971. A general coefficient of similarity and some of its properties. Biometrics, 27, 857-874.

Gower, J., Legendre, P., 1986. Metric and Euclidean properties of dissimilarity coefficients. Journal of Classification 3, 5-48.

Guénon, R., Vennetier, M., Pailler, A., Dupuy, N., Roussos, S., Gros, R., 2013. Trends in recovery of Mediterranean soil chemical properties and microbial activities after infrequent and frequent wildfires. Land Degradation and Development 24, 115-128.

Harguindeguy, N.P., Blundo, C.M., Gurvich, D.E., Diaz, S., Cuevas, E., 2008. More than the sum of its parts, Assessing litter heterogeneity effects on the decomposition of litter mixtures through leaf chemistry. Plant and Soil 303, 151-159.

Hättenschwiler, S., Tiunov, A.V., Scheu, S., 2005. Biodiversity and litter decomposition in Terrestrial Ecosystems. Annual Review of Ecology Evolution and Systematics 36, 191218. 
Hoorens, B., Aerts, R., Stroetenga, M., 2002. Litter quality and interactive effects in litter mixtures: more negative interactions under elevated $\mathrm{CO}_{2}$ ? Journal of Ecology 90, 1009-1016.

Iqbal, A., Beaugrand, J., Garnier, P., Recous, S., 2013. Tissue density determines the water storage characteristics of crop residues. Plant and Soil 367, 285-299.

Jensen, L.S., Salo, T., Palmason, F., Breland, T.A., Henriksen, T.M., Stenberg, B., Pedersen, A., Lundström, C., Esala, M., 2005. Influence of biochemical quality on $\mathrm{C}$ and $\mathrm{N}$ mineralisation from a broad variety of plant materials in soil. Plant and Soil 273, 307-326.

Jung, J.Y., Lal, R., Ussiri, D.A.N., 2011. Changes in $\mathrm{CO}_{2},{ }^{13} \mathrm{C}$ abundance, inorganic nitrogen, $\beta$-glucosidase, and oxidative enzyme activities of soil during the decomposition of switchgrass root carbon as affected by inorganic nitrogen additions. Biology and Fertility of Soils 47, 801-813.

Keeney, D.R., Nelson, D.W., 1982. Nitrogen in organic forms. In: Page, A.L., (Eds.) Methods of Soil Analysis. Part 2. Agronomy monograph, second ed. ASA and SSSA, Madison, WI, pp. 643-698.

King, H.G., Health, G.W., 1967. The chemical analyses of small samples of leaf material and the relationship between the disappearance and composition of leaves. Pedobiologia 7, 192-197

Lal R., Reicosky D.L., Hanson J.D., 2007 Evolution of the plow over 10,000 years and the rationale for no-till farming. Soil \& Tillage Research 93, 1-12.

Li, L.J., Han, X.Z., You, M.Y., Yuan, Y.R., Ding, X.L., Qiao, Y.F., 2013a. Carbon and nitrogen mineralization patterns of two contrasting crop residues in a Mollisol: Effects of residue type and placement in soils. European Journal of Soil Biology 54, 1-6.

Li, D., Peng, S., Chen, B., 2013b. The effects of leaf litter evenness on decomposition depend on which plant functional group is dominant. Plant and Soil 365, 255-266.

Liu, P., Sun, O.J., Huang, J., Li, L., Han, X., 2007. Nonadditive effects of litter mixtures on decomposition and correlation with initial litter $\mathrm{N}$ and $\mathrm{P}$ concentrations in grassland plant species of northern China. Biology and Fertility of Soils 44, 211-216.

Makkonen, M., Berg, M.P., Van Logtestijn, R., S.P., Van Hal, J.R., Aerts, R., 2013. Do physical plant litter traits explain non-additivity in litter mixtures? A test of the improved microenvironmental conditions theory. Oikos 122, 987-997.

Pavoine, S., Vallet, J., Dufour, A.B., Gachet, S.; Daniel H., 2009. On the challenge of treating various types of variables: application for improving the measurement of functional diversity. Oikos 118, 391-402.

Quemada, M., Cabrera, M.L., 1995. Carbon and nitrogen mineralized from leaves and stems of four cover crops. Soil Science Society of America Journal 59, 471-477.

Reinertsen, S.A., Elliott, L.F., Cochran, V.L., Campbell, G.S., 1984. The role of available $\mathrm{C}$ and $\mathrm{N}$ in determining the rate of wheat straw decomposition. Soil Biology \& Biochemistry 16, 459-464.

Recous, S., Robin, D., Darwis, D., Mary, B., 1995. Soil inorganic N availability: effect on maize residue decomposition. Soil Biology \& Biochemistry 27, 1529-1538.

Robinson, C.H., Kirkham, J.B., Littlewood, R., 1999. Decomposition of root mixtures from high arctic plants: a microcosm study. Soil Biology \& Biochemistry 31, 11011108.

Shi, A., Marschner, P., 2014. Changes in microbial biomass $\mathrm{C}$, extractable $\mathrm{C}$ and available $\mathrm{N}$ during the early stages of decomposition of residue mixtures. Soil Research 52, 366-372.

Tian, G., Brussaard, L., Kang, B.T., 1995. An index for assessing the quality of plant residues and evaluating their effects on soil and crop in the sub-humid tropics. Applied Soil Ecology 2, 25-32.

Thippayarugs, S., Toomsan, B., Vityakon, P., Limpinuntana, V., Pananothai, A., Cadish, G., 2008. Interactions in decomposition and mineralization between tropical legume residue 
components. Agroforestry Systems 72, 137148.

Trinsoutrot, I., Recous, S., Bentz, B., Linères, M., Chèneby, D., Nicolardot, B., 2000. Biochemical quality of crop residues and carbon and nitrogen mineralization kinetics under nonlimiting nitrogen conditions. Soil Science Society of America Journal 64, 918926.

Van Soest, P.J., 1963. Use of detergents in the analysis of fibrous feeds. I. Preparation of fiber residues of low nitrogen content. Journal of the Association of Official Analytical Chemists 46, 825-835.

Zeng, D.H., Mao, R., Chang, S.X., Li, L.J., Yang, D., 2010. Carbon mineralization of tree leaf litter and crop residues from poplarbased agroforestry systems in Northeast China: A laboratory study. Applied Soil Ecology 44, 133-137. 


\section{Final version of manuscript published in: Soil Biology and Biochemistry, 2014, DOI 10.1016/j.soilbio.2014.07.014}

Appendix A. Supplementary data: Coefficient of similarity between leaf and stem calculated for each chemical characteristics and each species using Gower's coefficient $\left(\mathrm{S}_{\mathrm{ijk}}\right)$ and aggregated similarity coefficient $\left(\mathrm{S}_{\mathrm{ij}}\right)$ calculated as the mean of $\mathrm{S}_{\mathrm{ijk}}$ for the whole set of characteristics.

\begin{tabular}{|c|c|c|c|c|c|c|c|c|c|c|}
\hline \multirow[t]{2}{*}{ Species } & \multicolumn{9}{|c|}{ Similarity coefficient $\left(\mathrm{S}_{\mathrm{ijk}}\right)$} & \multirow[b]{2}{*}{$\mathbf{S}_{\mathrm{ij}}$} \\
\hline & $\mathrm{SOL}^{\mathrm{a}}$ & HEM & CEL & LIG & $\mathrm{C}$ & $\mathrm{N}$ & $\mathrm{Csw}$ & Nsw & POL & \\
\hline $1-$ Bean & 0.09 & 0.28 & 0.16 & 0.17 & 0.29 & 0.52 & 0.24 & 0.38 & 0.54 & 0.30 \\
\hline 2 - Soybean & 0.00 & 0.29 & 0.06 & 0.00 & 0.80 & 0.67 & 0.11 & 0.37 & 0.58 & 0.32 \\
\hline 3 - Maize & 0.95 & 0.94 & 0.96 & 0.74 & 0.27 & 0.95 & 0.76 & 0.99 & 0.97 & 0.84 \\
\hline 4 - Sunflower & 0.47 & 0.89 & 0.16 & 0.92 & 0.66 & 0.54 & 0.37 & 0.62 & 0.00 & 0.51 \\
\hline 5 - Sunn hemp & 0.04 & 0.27 & 0.00 & 0.42 & 0.20 & 0.13 & 0.29 & 0.44 & 0.75 & 0.28 \\
\hline $6-$ Jack bean & 0.31 & 0.55 & 0.28 & 0.48 & 0.44 & 0.37 & 0.00 & 0.83 & 0.81 & 0.45 \\
\hline 7 - Gray mucuna & 0.44 & 0.90 & 0.33 & 0.38 & 0.34 & 0.20 & 0.25 & 0.94 & 0.91 & 0.52 \\
\hline 8 - Millet & 0.72 & 0.91 & 0.72 & 0.60 & 0.00 & 0.70 & 0.95 & 0.85 & 0.85 & 0.70 \\
\hline $9-$ Sorghum & 0.80 & 0.89 & 0.79 & 0.82 & 0.95 & 0.62 & 0.90 & 0.90 & 0.62 & 0.81 \\
\hline 10 - Showy rattlebox & 0.25 & 0.62 & 0.16 & 0.42 & 0.93 & 0.39 & 0.74 & 0.94 & 0.65 & 0.56 \\
\hline 11 - Black oat & 0.79 & 0.85 & 0.77 & 0.90 & 0.85 & 0.80 & 0.41 & 0.95 & 0.92 & 0.80 \\
\hline $12-$ Vetch & 0.59 & 0.65 & 0.64 & 0.59 & 0.76 & 0.45 & 0.58 & 0.84 & 0.76 & 0.65 \\
\hline $13-$ Wheat & 0.98 & 0.79 & 0.96 & 0.87 & 0.56 & 0.89 & 0.58 & 0.82 & 0.72 & 0.80 \\
\hline $14-$ Oilseed radish & 0.17 & 0.42 & 0.22 & 0.18 & 0.20 & 0.41 & 0.16 & 0.00 & 0.73 & 0.28 \\
\hline $15-$ Rye & 0.80 & 0.98 & 0.78 & 0.67 & 0.73 & 0.86 & 0.95 & 0.78 & 0.77 & 0.81 \\
\hline $16-$ Pea & 0.61 & 0.97 & 0.53 & 0.44 & 0.88 & 0.24 & 0.19 & 0.66 & 0.79 & 0.59 \\
\hline 17 - Triticale & 0.95 & 0.39 & 0.65 & 0.84 & 0.85 & 0.81 & 0.80 & 0.78 & 0.97 & 0.78 \\
\hline 18 - Oilseed rape & 0.06 & 0.00 & 0.28 & 0.14 & 0.54 & 0.60 & 0.39 & 0.45 & 0.72 & 0.35 \\
\hline 19 - Barley & 0.99 & 0.81 & 0.99 & 0.78 & 0.59 & 0.86 & 0.62 & 0.78 & 0.93 & 0.82 \\
\hline 20 - Ryegrass & 0.86 & 0.79 & 0.94 & 0.84 & 0.44 & 0.85 & 0.70 & 0.82 & 0.95 & 0.80 \\
\hline 21 - Castor bean & 0.13 & 0.41 & 0.03 & 0.54 & 0.54 & 0.38 & 0.68 & 0.85 & 0.20 & 0.42 \\
\hline 22 - Dwarf pigeonpea & 0.24 & 0.65 & 0.02 & 0.73 & 0.32 & 0.08 & 0.55 & 0.73 & 0.64 & 0.44 \\
\hline 23 - Blue lupine & 0.45 & 0.49 & 0.29 & 0.78 & 0.93 & 0.00 & 0.33 & 0.23 & 0.68 & 0.46 \\
\hline 24 - Native lupine & 0.37 & 0.39 & 0.48 & 0.43 & 0.98 & 0.17 & 0.35 & 0.60 & 0.64 & 0.49 \\
\hline 25 - Rice & 0.95 & 0.95 & 0.98 & 0.90 & 0.90 & 0.94 & 0.83 & 0.97 & 0.92 & 0.93 \\
\hline
\end{tabular}

${ }^{\text {a }}$ SOL: Soluble fraction (Van Soest); HEM: Hemicellulose; CEL: Cellulose; LIG: Lignin; C: Total organic carbon; N: Total nitrogen; Csw: Water-soluble carbon; Nsw: Water-soluble nitrogen; POL: Soluble polyphenols. 
Appendix B. Supplementary data: Weighted coefficient of similarity between leaf and stem calculated for each chemical characteristics and each species using Gower's coefficient weighted $\left(\mathrm{S}_{\mathrm{pij}}\right)$ and aggregated similarity coefficient $\left(\mathrm{S}_{\mathrm{ij}}\right)$ calculated for the whole set of characteristics. The weighted coefficients were calculated taking into account the proportion of leaf and stem masses in the mixtures.

\begin{tabular}{|c|c|c|c|c|c|c|c|c|c|c|}
\hline \multirow[t]{2}{*}{ Species } & \multicolumn{9}{|c|}{ Similarity coefficient $\left(\mathrm{S}_{\mathrm{pij}}\right)$} & \multirow[b]{2}{*}{$\mathbf{S}_{\mathrm{ij}}$} \\
\hline & $\mathrm{SOL}^{\mathrm{a}}$ & HEM & CEL & LIG & $\mathrm{C}$ & $\mathrm{N}$ & Csw & Nsw & POL & \\
\hline $1-$ Bean & 0.51 & 0.46 & 0.52 & 0.29 & 0.74 & 0.78 & 0.82 & 0.73 & 0.56 & 0.60 \\
\hline 2 - Soybean & 0.52 & 0.37 & 0.39 & 0.00 & 0.61 & 0.91 & 0.79 & 0.77 & 0.67 & 0.56 \\
\hline 3 - Maize & 0.87 & 0.00 & 0.47 & 0.52 & 0.21 & 0.95 & 0.92 & 0.89 & 0.88 & 0.63 \\
\hline 4 - Sunflower & 0.79 & 0.82 & 0.39 & 0.75 & 0.65 & 0.79 & 0.84 & 0.83 & 0.09 & 0.66 \\
\hline $5-$ Sunn hemp & 0.97 & 0.19 & 0.00 & 0.12 & 0.00 & 1.00 & 0.76 & 0.98 & 0.96 & 0.55 \\
\hline $6-$ Jack bean & 0.00 & 0.96 & 0.99 & 0.97 & 0.36 & 0.07 & 0.01 & 0.46 & 0.53 & 0.48 \\
\hline 7 - Gray mucuna & 0.78 & 0.81 & 0.59 & 0.43 & 0.80 & 0.66 & 0.86 & 0.97 & 1.00 & 0.77 \\
\hline 8 - Millet & 0.98 & 0.29 & 0.54 & 0.53 & 0.39 & 0.97 & 0.75 & 0.99 & 1.00 & 0.71 \\
\hline 9 - Sorghum & 0.79 & 0.87 & 0.99 & 0.92 & 0.85 & 0.70 & 0.91 & 0.89 & 0.47 & 0.82 \\
\hline 10 - Showy rattlebox & 0.94 & 0.55 & 0.31 & 0.32 & 0.39 & 0.99 & 0.96 & 0.84 & 0.94 & 0.69 \\
\hline 11 - Black oat & 0.88 & 0.84 & 0.86 & 0.91 & 0.93 & 0.89 & 0.78 & 0.99 & 0.92 & 0.89 \\
\hline $12-$ Vetch & 0.41 & 0.93 & 1.00 & 0.92 & 0.60 & 0.35 & 0.46 & 0.57 & 0.55 & 0.64 \\
\hline 13 -Wheat & 0.86 & 0.90 & 0.84 & 0.81 & 0.73 & 0.96 & 0.94 & 0.94 & 0.79 & 0.86 \\
\hline $14-$ Oilseed radish & 0.70 & 0.49 & 0.48 & 0.26 & 0.60 & 0.76 & 0.86 & 0.59 & 0.82 & 0.62 \\
\hline $15-$ Rye & 0.93 & 0.24 & 0.49 & 0.41 & 0.32 & 0.99 & 0.74 & 0.98 & 0.97 & 0.67 \\
\hline $16-$ Pea & 0.26 & 0.84 & 0.96 & 0.90 & 0.43 & 0.00 & 0.00 & 0.00 & 0.56 & 0.44 \\
\hline 17 - Triticale & 0.98 & 0.86 & 0.73 & 0.82 & 0.80 & 0.90 & 0.99 & 0.90 & 0.99 & 0.89 \\
\hline 18 - Oilseed rape & 0.85 & 0.04 & 0.36 & 0.10 & 0.32 & 0.90 & 0.98 & 0.85 & 0.93 & 0.59 \\
\hline 19 - Barley & 0.99 & 0.88 & 0.99 & 0.85 & 0.97 & 0.91 & 0.84 & 0.86 & 0.91 & 0.91 \\
\hline 20 - Ryegrass & 0.96 & 0.41 & 0.70 & 0.73 & 0.55 & 0.96 & 0.99 & 0.95 & 0.85 & 0.79 \\
\hline 21 - Castor bean & 0.33 & 0.63 & 0.60 & 0.74 & 0.97 & 0.57 & 0.85 & 0.89 & 0.00 & 0.62 \\
\hline 22 - Dwarf pigeonpea & 0.73 & 0.45 & 0.30 & 0.42 & 0.52 & 0.71 & 0.94 & 1.00 & 0.77 & 0.65 \\
\hline 23 - Blue lupine & 0.43 & 0.75 & 0.77 & 0.70 & 0.79 & 0.20 & 0.56 & 0.37 & 0.53 & 0.57 \\
\hline 24 - Native lupine & 0.52 & 0.61 & 0.78 & 0.64 & 0.97 & 0.44 & 0.72 & 0.73 & 0.56 & 0.66 \\
\hline 25 - Rice & 0.96 & 0.97 & 0.99 & 0.93 & 0.99 & 0.96 & 0.93 & 0.98 & 0.90 & 0.96 \\
\hline
\end{tabular}

${ }^{a}$ SOL: Soluble fraction (Van Soest); HEM: Hemicellulose; CEL: Cellulose; LIG: Lignin; C: Total organic carbon; N: Total nitrogen; Csw: Water-soluble carbon; Nsw: Water-soluble nitrogen; POL: Soluble polyphenols. 
Appendix C. Supplementary data: Cumulative residue-C mineralized and kinetic coefficients calculated from a simple exponential decay function for leaves, stems and mixture (leaf + stem) of plant residues incubated at $25^{\circ} \mathrm{C}$ during 120 days

\begin{tabular}{|c|c|c|c|c|c|c|c|c|c|}
\hline \multirow[t]{2}{*}{ Species } & \multicolumn{3}{|c|}{ Leaves } & \multicolumn{3}{|c|}{ Stems } & \multicolumn{3}{|c|}{ Leaf + Stem } \\
\hline & $\mathrm{C}$ min. measured $^{\mathrm{a}}$ & $\begin{array}{c}C_{0}^{\mathrm{b}} \\
\%\end{array}$ & $\begin{array}{c}k^{\mathrm{c}} \\
\mathrm{day}^{-1}\end{array}$ & $\begin{array}{c}\mathrm{C} \text { min. measured } \\
\%\end{array}$ & $\begin{array}{l}C_{0} \\
\%\end{array}$ & $\begin{array}{c}k \\
\text { day }^{-1}\end{array}$ & min. measured & $\begin{array}{l}C_{0} \\
\%\end{array}$ & $\begin{array}{c}k \\
\text { day }^{-1}\end{array}$ \\
\hline $1-$ Bean & $61.5 \mathrm{Ba}^{*}$ & 57.5 & 0.083 & $45.7 \mathrm{Cc}$ & 42.0 & 0.047 & $54.6 \mathrm{Bb}$ & 50.6 & 0.064 \\
\hline 2 - Soybean & $60.7 \mathrm{Ba}$ & 57.4 & 0.053 & $40.2 \mathrm{Db}$ & 41.4 & 0.024 & $49.9 \mathrm{Cab}$ & 47.8 & 0.033 \\
\hline 3 - Maize & $43.9 \mathrm{Ea}$ & 46.9 & 0.022 & $35.9 \mathrm{Fa}$ & 39.9 & 0.016 & $39.4 \mathrm{Da}$ & 41.1 & 0.022 \\
\hline 4 - Sunflower & $57.0 \mathrm{Ca}$ & 56.1 & 0.047 & $42.1 \mathrm{Db}$ & 56.1 & 0.012 & $57.7 \mathrm{Aa}$ & 60.7 & 0.022 \\
\hline 5 - Sunn hemp & $59.3 \mathrm{Ca}$ & 56.4 & 0.074 & $52.7 \mathrm{Ba}$ & 54.9 & 0.027 & $55.3 \mathrm{Ba}$ & 52.9 & 0.055 \\
\hline $6-$ Jack bean & $62.4 \mathrm{Ba}$ & 59.4 & 0.064 & $56.0 \mathrm{Aa}$ & 54.2 & 0.043 & $60.5 \mathrm{Aa}$ & 58.2 & 0.059 \\
\hline 7 - Gray mucuna & $61.5 \mathrm{Ba}$ & 56.5 & 0.066 & $57.1 \mathrm{Aa}$ & 53.1 & 0.051 & $60.5 \mathrm{Aa}$ & 56.0 & 0.059 \\
\hline $8-$ Millet & $65.9 \mathrm{Aa}$ & 63.6 & 0.046 & $51.0 \mathrm{Bb}$ & 53.7 & 0.023 & $55.2 \mathrm{Bb}$ & 54.1 & 0.030 \\
\hline 9 - Sorghum & $52.4 \mathrm{Da}$ & 50.3 & 0.058 & $50.4 \mathrm{Ba}$ & 47.6 & 0.037 & $51.2 \mathrm{Ba}$ & 49.0 & 0.051 \\
\hline 10 - Showy rattlebox & $56.4 \mathrm{Ca}$ & 54.1 & 0.088 & $53.8 \mathrm{Ba}$ & 49.6 & 0.061 & $53.9 \mathrm{Ba}$ & 49.2 & 0.072 \\
\hline 11 - Black oat & $61.9 \mathrm{Ba}$ & 61.6 & 0.045 & $46.6 \mathrm{Cc}$ & 44.8 & 0.036 & $54.2 \mathrm{Bb}$ & 53.2 & 0.042 \\
\hline $12-$ Vetch & $62.1 \mathrm{Ba}$ & 57.8 & 0.099 & $50.9 \mathrm{Bb}$ & 47.6 & 0.109 & $58.4 \mathrm{Aa}$ & 54.6 & 0.104 \\
\hline 13 - Wheat & $53.3 \mathrm{Da}$ & 51.3 & 0.038 & $42.7 \mathrm{Db}$ & 40.7 & 0.028 & $47.9 \mathrm{Cab}$ & 47.5 & 0.028 \\
\hline $14-$ Oilseed radish & $60.2 \mathrm{Ca}$ & 57.6 & 0.128 & $45.6 \mathrm{Cb}$ & 43.3 & 0.043 & $57.7 \mathrm{Aa}$ & 54.7 & 0.076 \\
\hline 15 - Rye & $51.6 \mathrm{Da}$ & 50.5 & 0.031 & $42.2 \mathrm{Db}$ & 49.4 & 0.016 & $42.0 \mathrm{Db}$ & 43.5 & 0.023 \\
\hline $16-$ Pea & $64.8 \mathrm{Aa}$ & 61.8 & 0.086 & $61.5 \mathrm{Aa}$ & 56.9 & 0.071 & $63.4 \mathrm{Aa}$ & 58.5 & 0.083 \\
\hline 17 - Triticale & 49.1 Da & 49.3 & 0.035 & $36.3 \mathrm{~Eb}$ & 39.1 & 0.022 & $40.9 \mathrm{Db}$ & 41.3 & 0.028 \\
\hline 18 - Oilseed rape & $61.6 \mathrm{Ba}$ & 59.1 & 0.108 & $48.1 \mathrm{Bb}$ & 47.2 & 0.049 & $57.8 \mathrm{Aab}$ & 55.0 & 0.068 \\
\hline 19 - Barley & $46.6 \mathrm{Ea}$ & 48.5 & 0.028 & $39.8 \mathrm{Db}$ & 39.8 & 0.025 & 41.6 Da & 41.8 & 0.032 \\
\hline 20 - Ryegrass & $51.0 \mathrm{Da}$ & 52.3 & 0.030 & $26.0 \mathrm{Fc}$ & 25.8 & 0.028 & $39.8 \mathrm{Db}$ & 41.8 & 0.021 \\
\hline 21 - Castor bean & $62.5 \mathrm{Ba}$ & 60.4 & 0.048 & $43.2 \mathrm{Db}$ & 39.7 & 0.034 & $53.3 \mathrm{Bab}$ & 50.3 & 0.048 \\
\hline 22 - Dwarf pigeonpea & $59.8 \mathrm{Ca}$ & 54.7 & 0.069 & $48.9 \mathrm{Bb}$ & 45.3 & 0.035 & $51.9 \mathrm{Bab}$ & 49.3 & 0.040 \\
\hline 23 - Blue lupine & $67.1 \mathrm{Aa}$ & 64.3 & 0.109 & $58.7 \mathrm{Ab}$ & 53.8 & 0.065 & $63.0 \mathrm{Aab}$ & 59.4 & 0.089 \\
\hline 24 - Native lupine & $61.8 \mathrm{Ba}$ & 57.4 & 0.078 & $52.6 \mathrm{Bb}$ & 48.9 & 0.051 & 57.7 Aab & 54.4 & 0.066 \\
\hline 25 - Rice & $55.8 \mathrm{Ca}$ & 54.7 & 0.035 & $38.2 \mathrm{Ec}$ & 38.4 & 0.032 & $46.9 \mathrm{Cb}$ & 46.6 & 0.035 \\
\hline
\end{tabular}

${ }^{\mathrm{a}}$ The $\%$ of added $\mathrm{C}$ mineralized from residues plant after 120 days.

${ }^{\mathrm{b}}$ Potentially mineralizable $\mathrm{C}$ pool.

${ }^{\mathrm{c}}$ Mineralization constant rate.

* Mean values with different large letters in the column are different by Scott-Knott test $(\mathrm{P}<0.05)$ and small letters in the lines by Tukey test $(\mathrm{P}<0.05)$. 
Appendix D. Supplementary data: Cumulative $\mathrm{CO}_{2}-\mathrm{C}$ evolved and soil mineral $\mathrm{N}$ of mixtures (leaf + stem residues) of 25 crop species, observed at day 14 and day 120 of incubation, and expected values calculated using results of single leaf and stem treatments, assuming additivity between mixture components.

\begin{tabular}{|c|c|c|c|c|c|c|c|c|}
\hline \multirow[t]{3}{*}{ Species } & \multicolumn{4}{|c|}{ Carbon min. ( $\%$ added $\mathrm{C})$} & \multicolumn{4}{|c|}{ Nitrogen min. (mg $\mathrm{N} \mathrm{kg}^{-1}$ soil) } \\
\hline & Measured & Expected $^{\mathrm{a}}$ & Measured & Expected & Measured & ected & Measured & Expected \\
\hline & $14 \mathrm{~d}$ & & 120 & days & 14 & 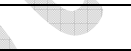 & 120 & lays \\
\hline $1-$ Bean & 625 & $634 \mathrm{~ns}$ & 1100 & $1133 *$ & 22.9 & $25.8 \mathrm{~ns}$ & 60.9 & $65.5 \mathrm{~ns}$ \\
\hline 2 - Soybean & 412 & $428 \mathrm{~ns}$ & 1068 & $1027 \mathrm{~ns}$ & 15.1 & $15.2 \mathrm{~ns}$ & 45.1 & $43.6 \mathrm{~ns}$ \\
\hline 3-Maize & 237 & $220 \mathrm{~ns}$ & 849 & $819 \mathrm{~ns}$ & 11.3 & $12.8 \mathrm{~ns}$ & 26.9 & $22.1 \mathrm{~ns}$ \\
\hline 4 - Sunflower & 274 & $227 *$ & 1152 & $960 *$ & 15.5 & $16.1 \mathrm{~ns}$ & 37.7 & $37.3 \mathrm{~ns}$ \\
\hline 5 - Sunn hemp & 458 & $513 \mathrm{~ns}$ & 1163 & $1142 \mathrm{~ns}$ & 31.6 & $33.2 \mathrm{~ns}$ & 65.1 & $69.7 \mathrm{~ns}$ \\
\hline $6-$ Jack bean & 706 & $691 \mathrm{~ns}$ & 1257 & $1260 \mathrm{~ns}$ & 82.4 & $93.7 *$ & 133.6 & $150.8 *$ \\
\hline 7 - Gray mucuna & 690 & $658 \mathrm{~ns}$ & 1264 & $1231 \mathrm{~ns}$ & 52.1 & $66.8 *$ & 104.5 & $118.9 *$ \\
\hline 8 - Millet & 432 & $404 \mathrm{~ns}$ & 1148 & $1158 \mathrm{~ns}$ & 18.9 & $24.0 \mathrm{~ns}$ & 42.8 & $43.0 \mathrm{~ns}$ \\
\hline 9 - Sorghum & 578 & $556 \mathrm{~ns}$ & 1090 & $1097 \mathrm{~ns}$ & 24.0 & $26.7 \mathrm{~ns}$ & 48.3 & $52.2 \mathrm{~ns}$ \\
\hline 10 - Showy rattlebox & 681 & $688 \mathrm{~ns}$ & 1100 & $1112 *$ & 34.7 & $27.9 *$ & 82.9 & $74.7 *$ \\
\hline 11 - Black oat & 516 & $524 \mathrm{~ns}$ & 1149 & $1202 \mathrm{~ns}$ & 12.8 & $11.7 \mathrm{~ns}$ & 39.6 & $38.3 \mathrm{~ns}$ \\
\hline $12-$ Vetch & 893 & $843 *$ & 1257 & $1188 *$ & 71.1 & $77.3 *$ & 121.2 & $129.5 *$ \\
\hline 13 - Wheat & 345 & $355 \mathrm{~ns}$ & 995 & $951 *$ & 5.5 & $5.6 \mathrm{~ns}$ & 28.3 & $26.8 \mathrm{~ns}$ \\
\hline $14-$ Oilseed radish & 709 & $591 *$ & 1113 & $997 *$ & 14.7 & $18.9 \mathrm{~ns}$ & 46.1 & $56.7 \mathrm{~ns}$ \\
\hline $15-$ Rye & 278 & $308 *$ & 911 & $998 *$ & 13.6 & $13.0 \mathrm{~ns}$ & 38.9 & $34.0 \mathrm{~ns}$ \\
\hline $16-$ Pea & 811 & $829 \mathrm{~ns}$ & 1305 & $1312 \mathrm{~ns}$ & 83.9 & $98.3 *$ & 129.2 & $167.1 *$ \\
\hline 17 - Triticale & 309 & $306 \mathrm{~ns}$ & 881 & 904 ns & 16.1 & $15.2 \mathrm{~ns}$ & 33.4 & $37.4 \mathrm{~ns}$ \\
\hline 18 - Oilseed rape & 640 & $586 \mathrm{~ns}$ & 1138 & $1014 *$ & 28.8 & $32.1 \mathrm{~ns}$ & 78.1 & $72.2 \mathrm{~ns}$ \\
\hline 19 - Barley & 309 & $277 *$ & 873 & $907 \mathrm{~ns}$ & 10.7 & $9.2 \mathrm{~ns}$ & 37.6 & $34.1 \mathrm{~ns}$ \\
\hline 20 - Ryegrass & 274 & $255 *$ & 876 & $761 *$ & 7.3 & $9.3 \mathrm{~ns}$ & 39.0 & $41.3 \mathrm{~ns}$ \\
\hline 21 - Castor bean & 543 & $537 \mathrm{~ns}$ & 1076 & $1119 \mathrm{~ns}$ & 16.1 & $18.2 \mathrm{~ns}$ & 58.2 & $50.9 *$ \\
\hline 22 - Dwarf pigeonpea & 551 & $582 \mathrm{~ns}$ & 1165 & $1159 *$ & 34.2 & $37.8 *$ & 71.6 & $76.2 *$ \\
\hline 23 - Blue lupine & 886 & $883 \mathrm{~ns}$ & 1325 & $1323 \mathrm{~ns}$ & 53.5 & $74.5 *$ & 121.9 & $124.2 \mathrm{~ns}$ \\
\hline 24 - Native lupine & 709 & $688 *$ & 1226 & $1211 \mathrm{~ns}$ & 59.9 & $57.2 \mathrm{~ns}$ & 102.9 & $100.3 \mathrm{~ns}$ \\
\hline 25 - Rice & 343 & $334 \mathrm{~ns}$ & 853 & $855 \mathrm{~ns}$ & 8.9 & $10.7 \mathrm{~ns}$ & 34.1 & $32.8 \mathrm{~ns}$ \\
\hline
\end{tabular}

${ }^{\mathrm{a}}$ Expected values are calculated according to the proportion of leaves and stems in the mixtures (see Table 1). Asterisks in the lines indicate significant difference of means by Tukey test $(\mathrm{P}<0.05)$. Not significant (ns). 